OPEN ACCESS

Edited by:

Sara Hughes,

University of Michigan, United States

Reviewed by:

Erik Porse,

California State University

Sacramento, United States

Saruhan Mosler,

Writtle University College

United Kingdom

${ }^{*}$ Correspondence:

Luna Khirfan

Ikhirfan@uwaterloo.ca

Specialty section:

This article was submitted to Water and Built Environment,

a section of the journal

Frontiers in Water

Received: 06 August 2021 Accepted: 22 October 2021 Published: 02 December 2021

Citation:

Khirfan L, Mohtat N and Daub B (2021) Reading an Urban Palimpsest: How the Gradual Loss of an Urban

Stream Impacts Urban Form's

Connections and Ecosystem Functions. Front. Water 3:754679. doi: 10.3389/frwa.2021.754679

\section{Reading an Urban Palimpsest: How the Gradual Loss of an Urban Stream Impacts Urban Form's Connections and Ecosystem Functions}

\author{
Luna Khirfan*, Niloofar Mohtat and Ben Daub \\ School of Planning, University of Waterloo, Waterloo, ON, Canada
}

Fluvial reclamation to facilitate urban development leads to culverting, hence, a loss of urban streams. Using the palimpsest analogy, we examine how the Amman Stream in Amman (Jordan) historically provided regulatory and socio-cultural ecosystem services through its socio-spatial (longitudinal, lateral, and vertical) connections. We then explore the impact of the stream's culverting, partially in 1967 then completely in 1997, on these connections and, consequently, on ecosystem services. To overcome data paucity, our methodology relied on constructing spatial data by georeferencing and digitizing aerial photos and satellite images (from 1953, 1975, 1992, and 2000) using ArcGIS. We augmented our data with archival research (historic and contemporary documents and maps), an online survey among Amman's residents, and in situ observations and photography. The results reveal striking contrasts between the historic and contemporary configuration of urban form vis-à-vis the Amman Stream. Throughout its early urban history during the Classical and early Islamic periods, the urban form elements reflected reverence and prudence toward the Amman Stream as manifested in the investment in water infrastructure and the alignment of thoroughfares, civic monuments, and bridges that collectively capitalized on the land relief (the strath) and established strong connections with the Amman Stream, maximizing, in the process, its regulatory and socio-cultural services. In contrast, the contemporary urban form replaced the stream with car-oriented roads, hence, eradicated its regulatory services and replaced its socio-spatial connections with urban socio-economic and cultural fissures. Accordingly, we propose to daylight (de-culvert) the Amman Stream to restore its regulatory and socio-cultural services and its socio-spatial connections. We substantiate the feasibility of daylighting through: (1) morphological analysis that reveals that roads cover most of the stream; (2) the survey's findings that indicate public support; and (3) the cascading benefits for the larger watershed in a water insecure region.

Keywords: the Amman Stream (Seil Amman), Jordan, regulatory ecosystem services, socio-cultural ecosystem services, urban form, ecosystem loss, urban palimpsest, urban form connections 


\section{INTRODUCTION: FLUVIAL RECLAMATION AND THE LOSS OF URBAN STREAMS}

Twentieth century rapid urbanization increased the demand on developable land in urban areas, which often led to land reclamation. Initially, land reclamation was carried out for agricultural purposes (e.g., for flood control, drainage, and irrigation) whereby land was acquired from water through draining and leveling. Land reclamation, however, expanded since the 1940s to increase developable urban land triggered by the combination of advances in construction technologies and increase in urbanization demands for housing, industrial, and commercial functions (McComas, 1972). While most of the discourse focuses on coastal land reclaimed from the sea, an often-overlooked type is fluvial reclamation-i.e., the reclamation of land from urban streams and rivers by culverting them and diverting them into underground pipes. Akin to coastal land reclamation, fluvial land reclamation facilitates land development over the culverted or channeled urban streams and rivers. Accordingly, many urban streams, and their associated ecosystem services, disappeared from the urban landscape (Broadhead et al., 2015). The rise of environmental awareness since the 1970s and, more recently, the increasingly accelerating risks from climatic hazards, led to calls for nature-based interventions that restore and/or reintroduce lost ecosystems, and by consequence, their services, into the urban landscape (Kabisch et al., 2016), among which is the daylighting (i.e., de-culverting) of buried streams (Wild et al., 2019). Stream daylighting refers to "the practice of removing streams from buried conditions and exposing them to the Earth's surface in order to directly or indirectly enhance the ecological, economic and/or socio-cultural well-being of a region and its inhabitants"(Khirfan et al., 2020a, p. 10).

To date, however, there is a dearth of studies that connect urban streams, particularly their culverting and/or daylighting, and urban form-a feat that this study accomplishes. We investigate in this study the impacts of the loss of an urban stream in Amman, Jordan's capital on the urban form and on ecosystem services. Specifically, we focus on the longitudinal, vertical, and lateral connections between streams and urban form (Kondolf and Pinto, 2017) as well as on the regulatory ecosystem services (stormwater management) (Wild et al., 2011) and on the socio-cultural services (various levels of meanings associated with urban streams) (Smith, 2007). Using a palimpsest analogy (Khirfan, 2010, 2011), our research design investigates the change over time in Amman's urban form vis-à-vis the loss of the Amman Stream through culverting. Our methodology combines four strategies: archival research, spatial analysis of Amman's historical and contemporary maps (using ArcGIS), an online survey among Amman's residents (refer to Supplementary Material), and last, in situ observations and photography.

We begin our study with a brief introduction of the connections between urban streams and urban form, then we discuss the loss of ecosystems, with a particular focus on urban streams and this loss's repercussion for ecosystem services. Our discussion delves deeper into the regulatory and the sociocultural of urban streams with a particular emphasis on the
Near East, the region where Amman, the focus of this study, is located. We then home in on the case study, the Amman Stream and describe our research methodology followed by the findings and discussion.

\section{URBAN STREAMS AND URBAN FORM: INTRINSIC SOCIO-SPATIAL CONNECTIONS}

The study of urban form, known as urban morphology, is concerned with three elements: the town plan, the building and land uses, and the three-dimensional built form. The town plan consists of the streets and their networks, buildings and their footprints, and plots and their compilation into blocks (Conzen, 1960). Underpinning the development of the town plan, however, is the underlying natural geographic context upon which it was built-known as the land relief (Oliveira, 2016). This pre-urbanization land relief form impacts the position, outline, and arrangement of the town plan's elements, hence, shapes the settlement's morphological tissue (Kropf, 1996).

Accordingly, the synergy between urban streams and rivers and urban form is complex (Penn, 2001; Solomon, 2011; Phong, 2015; Mosler, 2021) whereby each influences the other and both are influenced by the settlement's social, economic, and cultural conditions (Silva et al., 2006; Abshirini and Koch, 2016; Mosler, 2021). There are nevertheless clear longitudinal, lateral, and vertical socio-spatial connections between streams and the town plan (Kondolf and Pinto, 2017). Longitudinal connections relate to the socio-spatial routes defined by streams and rivers along their length. For example, at a regional scale, in Iraq, the Tigris waterway runs over $400 \mathrm{~km}$ between Baghdad and Mosullongitudinally connecting these two cities and several others along the way (Karamouz and Nazif, 2008). At an urban scale, the Beirut River shaped two main parallel roads that separate Beirut's core from its suburbs (Youssef and Ali, 2017). As for the lateral connections, they refer to the socio-spatial connections across rivers and streams such as bridges and dams. For instance, the historical Jolfa and Khaju bridges across the Zayandeh-rood river in Isfahan (Iran) connect the northern and southern sides of the city's street network while also providing urban public spaces for people (Faizi and Omrani, 2012). Last, the vertical connections refer to the socio-spatial (i.e., morphological) arrangements that allow people use riverbanks or their upper spaces. For example, the embankments of the Tigris River in the historic town of Hasankeyf, Turkey have historically provided a space for recreational activities, swimming, and fishing for both locals and tourists (Schmandt and Kibaroglu, 2016).

Furthermore, as greater numbers of urban streams are culverted the longitudinal, lateral, and vertical socio-spatial connections between them and their urban context are impacted (Kondolf and Pinto, 2017). The loss of longitudinal connections limits the permeability of the urban form, leading to inaccessibility through ecological green/blue corridors (Walmsley, 1995; Kang and Cervero, 2009), resulting in the elimination of social activities such as running, walking, and bicycling, among others (Imam, 2006). Lateral connections, when lost, terminate the connectivity of urban patches across 
bridge pathways, leading to the fragmentation of urban landscapes. Such a loss deprives local communities (on both sides of a river) of social interactions and of participation in reciprocal activities like gathering, relaxing, and fishing as they are effectively limited to being on one side of the river (Gobster and Westphal, 2004; Angel et al., 2012). Last, the loss of vertical connections affects the types and varieties of uses and functions along riverbanks, restricting social activities like picnicking, swimming, diving, and paddling that require access to the rivers' water and their banks (Searns, 1995; Kondolf and Yang, 2008).

\section{URBAN ECOSYSTEMS: WHAT'S IN A LOSS?}

The unprecedented urbanization of lands during the twentieth century spurred on by demands for housing, industrial, and commercial functions, which is expected to be tripled by the year 2030, has led to the degradation, and consequently, the loss of several natural ecosystems (Elmqvist et al., 2013; Chou, 2016; Lyu et al., 2018). If we consider natural ecosystems as "a set of interacting species and their local, non-biological environment functioning together to sustain life" (Bolund and Hunhammar, 1999 , p. 294), then inevitably, the loss of ecosystems results in the disappearance of both biological species and the nonbiological natural environment, such as forests, trees, wetlands, rivers, and even, soil among others (see Agbeja, 2010; Gurung et al., 2012; Kim and Petrolia, 2013; Collier, 2015; Song and Deng, 2015; Elmqvist et al., 2016; Shirazi and Kazmi, 2016; Mundoli et al., 2017). Perhaps one of the most radical manifestations of ecosystem loss in favor of urbanization is fluvial reclamation-i.e., the reclamation of land from urban watercourses (streams and rivers) by culverting them and diverting them into underground pipes. Such loss negatively impacts, if not altogether eliminates, the four groups of ecosystem services -i.e., the benefits humans in/directly perceive from natural ecosystems: provisioning, supporting, regulating, and cultural (Costanza et al., 1997; Wallace, 2007; Yeakley et al., 2016).

The loss of urban watercourses impacts provisioning services, or the goods produced by these watercourses as natural ecosystems, such as the loss of fish in Brazil's degraded Capibaribe river, which forced the local communities to change their livelihood and diet (Collier, 2015). Such loss also impacts supporting services, in reference to the services necessary for the production of other ecosystem services, such as the reduced biotic richness in three buried streams near the city of Cincinnati in Ohio, USA (Beaulieu et al., 2015). Moreover, the elimination of watercourses from the urban landscape yields cascading negative impacts for a slew of regulating services that moderate natural phenomena, such as water filtration (Arnott, 2017) and erosion control (Charbonneau and Resh, 1992). Last, when urban watercourses are lost, ensues in negative non-monetary impacts on cultural services, such as the sense of personal loss and nostalgia that ensued from the degradation of Lower Kaskaskia River in Illinois, USA (Slemp et al., 2012). This paper delves deeper into the latter two ecosystem services with regards to urban streams, namely the regulatory and the socio-cultural services with a particular focus on the Near East.

\section{Regulatory Ecosystem Services: More Than Just Water Under the Bridge}

Regulatory ecosystem services play a crucial role in environmental stability as they provide natural means of water filtration (Arnott, 2017), erosion control (Charbonneau and Resh, 1992), temperature moderation (Everard and Moggridge, 2012), and draining and discharging capacity (Yeakley et al., 2016), each of which contribute to overall human wellbeing (Zhang et al., 2021). The loss of these regulatory services may be profound and widespread and could entail an increased vulnerability to storms (Kim and Petrolia, 2013), heightened environmental degradation (Gurung et al., 2012), and decrease in wildlife (Collier, 2015). An example of the detrimental impact of the loss of regulatory ecosystem is the destruction of the Huleh wetlands in Israel, which was perceived as a breeding ground for malaria, hence, drained (Tal and Katz, 2012). Subsequently, a slew of negative impacts developed, including soil infertility and, during the summer months, frequent dust storms and soil erosion into the Kinneret Lake while winter months witnessed severe flooding that further exacerbated soil erosion (Hambright and Zohary, 1998; Cohen-Shacham et al., 2011). Similarly, the drainage of the Mesopotamian Marshlands in the TigrisEuphrates River basin in Iran and Iraq to expand oil extraction altered the rivers' regulatory services whereby natural inundation and water delivery processes across the wetland were lost which resulted in evapotransporative and agricultural challenges in the region (Chen et al., 2011).

Fluvial reclamation profoundly impacts the regulatory capacity of urban streams as natural ecosystems. The consequences of culverting watercourses on flood risks have been documented since the mid 1990s (Pinkham, 2000; CIWEM, 2007), particularly concerning the culverts' fixed drainage capacity that precludes streaming excess rainwater (Gregory and Chin, 2002; Chou, 2013) and their high probability of blockage by sediments and debris (Wild et al., 2011; Broadhead et al., 2013). Moreover, the impervious surfaces that typically cover the buried streams (e.g., concrete pavements and asphalt roads) prevent the soil's absorption of excess rainwater (Jin, 2016; Tuler et al., 2016; Weitzell et al., 2016), which causes surplus rainwater to flow over these surfaces, leading to rainwater runoff (Wild et al., 2019; Sohn et al., 2020).

With the more severe and frequent extreme weather events attributed to climate change (CIWEM, 2007; Chou, 2013), such runoff is more and more causing inundation in urban areas. Surely, empirical evidence points to a correlation between increased inundation from rainwater runoff and the locations of lost rivers. For example, Zürich's (Switzerland) urban expansion during the nineteenth and twentieth centuries entailed burying over $100 \mathrm{~km}$ of urban streams and led to severe floods (Conradin and Buchli, 2004). Similarly, Genoa's (Italy) 2014 flash flood is attributed to the culverting of 28 of the city's 66 urban streams (Faccini et al., 2018) while Yonkers's (New York, USA) frequent sewage overflows during the 1990s were the 
adverse consequences of culverting the Saw Mill River in 1920 (García, 2017). In the Near East, Istanbul's (Turkey) consistent flooding between 1999 and 2009 ensued from the burial and channelization of the Ayamama Stream which resulted in frequent loss of life and property damage (Delibas and Tezer, 2017).

\section{Socio-Cultural Ecosystem Services: From the Esoteric to the Quotidian}

The negative impacts that ensue from the loss of urban ecosystems also include a loss of socio-cultural services in reference to the intangible, non-monetary, and ecologically focused factors that influence human wellbeing (van Riper et al., 2017). These encompass the connections between urban ecosystems and urban residents including the latter's recreational, spiritual, and aesthetic scenic values that contribute to a city's sense of place (also see Zube et al., 1998; Winthrop, 2014). In the Near East, where this paper's case study is located, and in other regions where water scarcity prevails, the socio-cultural services provided by urban streams assume a particular significance.

Most of the earliest cities around the world, and especially in the ancient Near East, evolved around streams and rivers spurred by a surplus from agricultural activities (Macklin and Lewin, 2015). While major rivers like the Nile (in modern day Sudan and Egypt) and the Tigris and Euphrates (in modern day Iraq and Syria) are well known as cradles of civilization ${ }^{1}$, it is in fact the smaller and lesser known streams and rivers in the Near East that hosted some of the earliest cities in the world, such as Apamea, Homs, and Hama along the Orontis ${ }^{2}$ and Damascus along the Barada River (Syria); Jericho by the Ein es-Sultan stream, one of the River Jordan's tributaries (the Palestinian Territories); and Beirut by the Beirut River (Lebanon). Yet, paradoxically, most of the Near Eastern countries currently struggle with water scarcity leading to water insecurity including, Jordan, Syria, and Israel (Falkenmark, 1989; Weinthal et al., 2015). Such water scarcity led to complex and multi-dimensional spatial and sociocultural interactions between Near Eastern cities and their urban streams and rivers. To better understand these interactions, we adapt Amos Rapoport's (Rapoport, 1988, 1990) three levels of socio-cultural meanings of urban form elements (like buildings and plazas) to include urban streams. We do so based on the consideration that urban streams are part of the land relief that contributed to shaping urban form (see Kropf, 1996; Oliveira, 2016 on land relief).

The first level of meaning pertains to the esoteric cosmic connections, or higher-level meanings of urban form elements (also see Rykwert, 1976; Lynch, 1981; Smith, 2007) that we adapt to the rivers and streams intertwining with urban form. For example, Beirut's (Lebanon) stream, known as "Adonis" or "Nahr Ibrahim" was dotted with shrines and other places of worship and sacred spaces where sacrifices, including human ones, were offered in reverence of the river's spring floods that brought fertile soil downstream (Penn, 2001). The reverence of

\footnotetext{
${ }^{1}$ Uruk, which is considered the earliest city in the world developed along the Euphrates https://www.worldhistory.org/city/.

${ }^{2}$ The Orontis flows from Lebanon through Syria to Turkey.
}

urban streams and rivers continued through the Hellenistic and Roman periods ${ }^{3}$ as evidenced in the construction of Nymphaea (singular Nymphaeum). Nymphaea are water-specific shrines and temples dedicated for the nymphs or river gods who are the spirits that guard the sources of pure water (Walker, 2012; Kopestonsky, 2016). Constructed along urban streams and rivers, Nymphaea were civic structures that often contained pools, and fountains and functioned as the primary source of water for urban populations (Kadhim, 1993; Curl and Wilson, 2015). The mythology behind Nymphaea and their association with the fertility and abundance of urban streams and rivers thus acquired higher meanings especially when juxtaposed against the Near East's water scarcity (Aken, 1951). Nymphaea dotted several Hellenistic cities in the Near East, especially the Decapolis cities, which were a league of ten prominent cities (one of which was ancient Philadelphia or modern-day Amman) that continued to be inhabited throughout the subsequent Roman, Byzantine, and Umayyad periods $^{4}$ (see Lucke et al., 2005; Livingstone, 2013).

The second medium-level meanings pertain, according to Rapoport $(1988,1990)$, to the geometric spatial arrangements of urban form's elements like the town plan. Such arrangements display identity, status, and power through, for example, symmetry, axiality, and the spatial organization of buildings (also, see Smith, 2007). These, too, we adapt to urban streams and rivers in the Near East where the significance of water symbolism was conveyed through the location of the urban settlement and its urban form. Indeed, from their earliest formation in the Near East during the Chalcolithic (4500-3300 BC) and Early Bronze Age (3300-2100 BC), human settlements mostly developed near streams (Albright, 1925; Cordova, 2007). During the subsequent Hellenistic and Roman periods access to water was closely tied to long-term prosperity (Lichtenberger and Raja, 2020) and as such, formed a central and integral part of urban form. This is most aptly discerned through the morphological arrangement of urban settlements like the Decapolis Cities where archaeological evidence reveals how major civic structures and thoroughfares (like the north-south Cardo and the east-west Documani) were aligned with the streams. For instance, Gadara (modern-day Jerash in Jordan) was also known as Antioch on the Golden River (Lichtenberger et al., 2019; Lichtenberger and Raja, 2020) to underscore its strong ties with the river. Moreover, Gadara's land relief-a shallow north-south valley where the river ran surrounded by hills on both sides-shaped its urban form. Gerasa's Golden River divided the city into a residential east and a civic and monumental west (see also Browning, 1982; Al-Kheder and Khrisat, 2007). The Cardo, the city's north-south main thoroughfare, ran parallel to the river while the two Documani ran perpendicular to both. Situated, figuratively and literally, at the center of the city is the Nymphaeum as a symbol of the central role that water played in the city's life (Figure 1).

Lastly, lower-level meanings pertain to the nexus between the urban form elements and the public perception of how they are

\footnotetext{
${ }^{3}$ The Hellenistic period in the Levant, Near East started with Alexander the Great's invasion around $333 \mathrm{BC}$ while the Roman period began in $63 \mathrm{AD}$.

${ }^{4}$ The Byzantine period in the Near East began in 395AD while the Umayyad Period began in 661 and lasted until 750AD.
} 


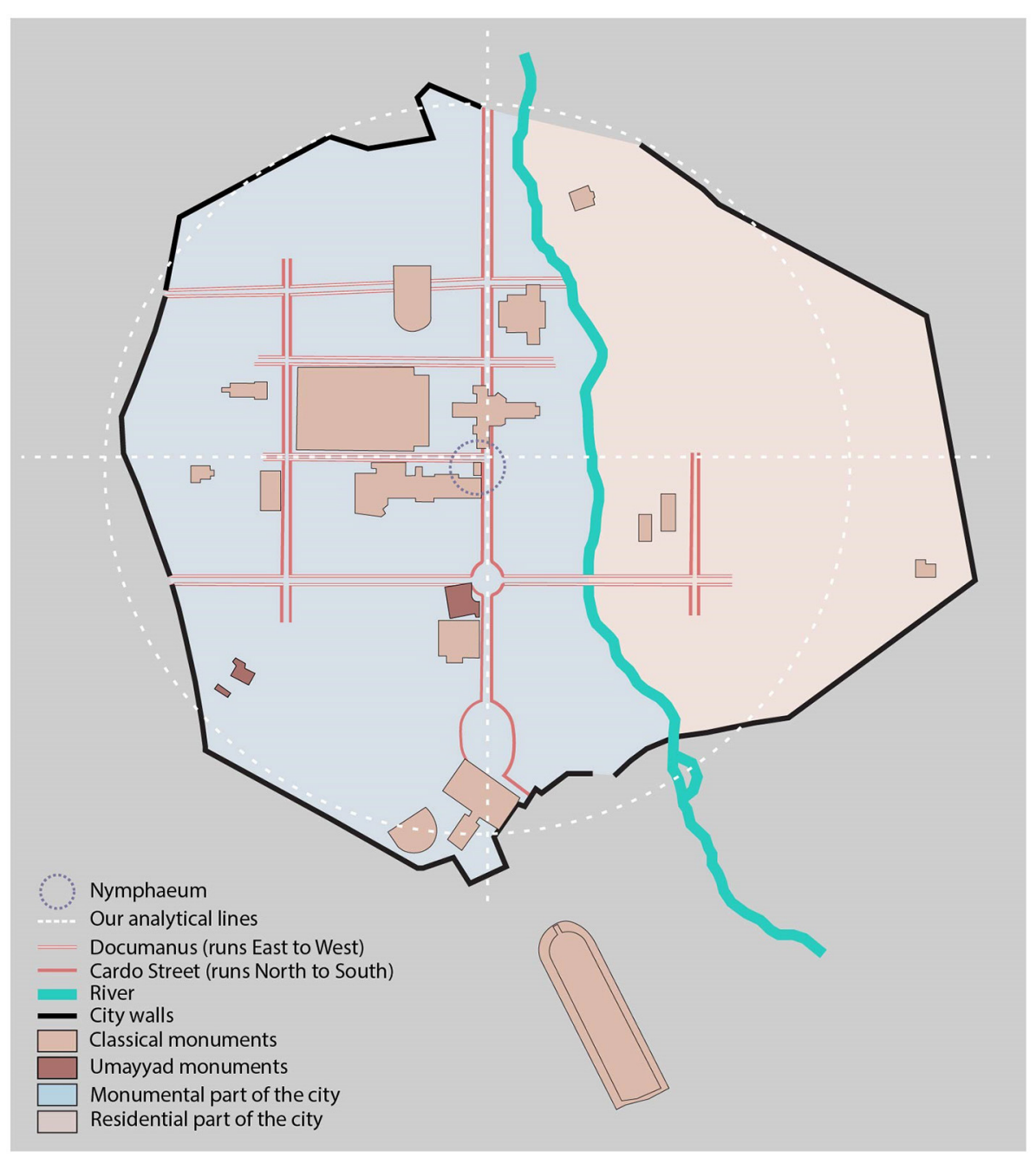

FIGURE 1 | Classical era Gerasa's (contemporary Jerash) town plan showing the central location of the Nymphaeum and the strong connections to its Golden River (reproduced after Browning, 1982, p. 83 by Sophie Wang under the supervision of Dr. Luna Khirfan-analysis ours).

used (see Rapoport, 1988, 1990; Smith, 2007). Our adaptation of these meanings focuses on the intrinsic values and meanings associated with the quotidian urban activities that occur in relation to urban streams and rivers. Despite the mundane nature of lower-tiered meanings, urban streams held considerable value and use in the day to day lives of the Near East. To begin, urban rivers and streams were essential for provision whether it was for potable water and fishing, hunting and gathering, or agriculture along their banks (Campbell, 2012; Maniatakou et al., 2020). Additionally, other economic activities developed along the banks of urban streams and rivers, including tanning and water mills for grinding wheat (Van Bavel et al., 2018). Particularly in the Near East's (semi-)arid climate, economic activities instigated innovative water management strategies that regulated human consumption, agricultural activities, and even microclimate. Examples abound from the region, including the hydraulic system in Shoushtar (Iran) that directs the Karoun River's waters into a series of human-made dams, channels, and streams (Mahdavinejad et al., 2013; Moghaddam, 2014) and the
Aflaj irrigation system deployed throughout Omani cities in the Arabian Peninsula, which tap into underground aquifers and deliver water to settlements via tunneled channels (Al-Marshudi, 2001; Ahmed, 2015). Streams also provided mild microclimates in the hot and arid Near East (Ali et al., 2017), and as such became spaces that are conducive to relaxation and enjoyment such as through picnicking along Damascus's Barada River (Akkach, 2010) hunting, fishing, and gathering along the banks of Wadi Kubbaniyya stream (Egypt), and even quotidian activities like washing and laundry along the banks of Shatt-al-Arab in Basra (Iraq) (Coad and Al-Hassan, 1989).

\section{AMMAN'S URBAN WATERCOURSES: FROM ABUNDANCE TO SCARCITY}

Amman, Jordan's capital, is located on a plateau that ranges between 800 and $1,200 \mathrm{~m}$ above sea level (lowest in East Amman and highest in West Amman). Its climate is arid 
with $245 \mathrm{~mm}$ average annual precipitation most of which falls between November and March with rare occasional precipitation in September through October and/or in April through May. June through August are months without any rainfall. January is the coldest month in the year (average temperature ranges between a $3.6^{\circ} \mathrm{C}$ low and $12.3^{\circ} \mathrm{C}$ high) while August is the hottest month (average temperature ranges between an $18.6^{\circ} \mathrm{C}$ low and a $32.4^{\circ} \mathrm{C}$ high $)^{5}$.

Amman is steeped in history. Archeological discoveries indicate that it was first settled 12,000 years ago and remained continuously inhabited throughout the Chalcolithic Period (4500-3300 BC), the Bronze Age (3600-1200 BC), and the Iron Age (1200-332 BC) when it was known as Rabbath Ammon (Albright, 1925; Simmons et al., 1988; Northedge, 1992d; Kennedy, 2017). During the Hellenistic period following Alexander the Great's conquest (333-64 BC), it became known as Philadelphia (after Ptolemy the II Philadelphus)-a name that continued during the Roman (64 BC-324 AD) and Byzantine periods (324-636 AD). Philadelphia maintained prominence throughout most of the Classical period as one of the Decapolis cities (Hübner, 1992; MacAdam, 1992). By the Umayyad period (the first Muslim dynasty that reigned from 661 to $750 \mathrm{AD}$ ), Philadelphia reverted to its Semitic name, Amman and continued to be inhabited until around 749-750 AD when it was abandoned probably due to a combination of the devastating Galilee earthquake in $749 \mathrm{AD}$ (see Marco et al., 2003; Ambraseys et al., 2005) and the end of the Umayyad Dynasty in 750 AD. Except for a few nomadic Bedouin tribes, Amman remained abandoned and sparsely populated until the nineteenth century when Circassians tribes, displaced from contemporary Russia, migrated to Amman. In 1921, while under British Mandate, Amman became the capital of the newly founded Transjordan, and since then its population continued to grow rapidly fueled by waves of political asylum seekers and refugees fleeing regional political instability (Khirfan, 2019). According to the 2015 census data, Jordan's total population is 9.5 million, while Amman's is slightly over 4.0 million. There are, officially, 2.9 million (30.6\%) foreign citizens who live in Jordan, half of whom (49.7\%) live in Amman compared to only $38.6 \%$ of Jordanian citizens who live in Amman (Department of Statistics, 2015). Interestingly, the settlement pattern aligned with the land relief whereby most of the incoming refugees concentrated in the south-east side of the Amman Stream, while the more affluent resided on the northwest side of the stream. As such, the strath that formed the Amman Stream became, in addition to being a natural divide, a socio-economic and cultural one between an affluent "West" and an impoverished "East" Amman.

Rapid urban development paralleled this population growth since the 1940s, which radiated around the city's core (Kadhim and Rajjal, 1988). This developmental approach ultimately led to the loss of several ecosystems, primarily urban watercourses through fluvial reclamation, the most significant of which is the Amman Stream that was culverted in two phases. The first, in 1967 when, at the advice of British experts (Hacker,

${ }^{5}$ Sources are the Weather Atlas: https://www.weather-atlas.com/ and World Climate Guide https://www.climatestotravel.com/.
1960), culverted the western segment of the stream between the Hashemite Plaza in front of the Classical era Theater and a point that became locally knows as Sagf el-Seil (literally translates to "the ceiling over the stream") where the stream flowed in underground culverts. The second phase, in 1997 when a new compound for the Greater Amman Municipality Head Offices was constructed, led to the culverting of the remaining exposed parts of the stream starting from its source at Ras Al-Ain to Sagf al-Seil (Sakr, 2013; Peck and Khirfan, 2021). Between 2009 and 2011, a newly-designed Hashemite Plaza surrounding the Classical era Theater and Odeum was constructed during which, to the chagrin of Amman's residents, a green park with mature trees and a local market were demolished (Abu-Khafajah and $\mathrm{Al}$ Rabady, 2013).

\section{THE URBAN PALIMPSEST: EXPOSING A STREAM'S LOSS}

Since settlements are given meaning by those who inhabit them (see Smith, 2007) and since societal values continuously change (Baniasadi and Dastmalchian, 2014), the ensuing urban form is consistently locked in a dynamic state of flux (Inam, 2014). Despite this, or maybe because of it, traces of past urban form, and past land relief including urban streams, remain visible in the urban landscape akin to traces on a palimpsest-a piece of parchment that is continually effaced and reused but with past traces visible on it (Khirfan, 2010, 2011). Because fluvial reclamation in urban areas frequently occurs gradually, the impacts on urban watersheds (Weitzell et al., 2016) and, we propose, on urban form are also cumulative and gradual. Analyzing morphological change over time, and the direct impacts that town plan alteration has had on the urban form and watercourses can be effectively used to discern the impacts of the loss of regulatory and socio-cultural ecosystem services, such is the lens through which this research was conducted. Accordingly, we apply an urban palimpsest approach to investigate the impacts of the loss of an urban stream, the Amman Stream in this case, on the city's urban form and on its ecosystem services.

Specifically, through studying different historical layers of Amman's urban palimpsest, this study investigates the historical and present-day evolution of the urban form vis-à-vis the Amman Stream to: (1) identify how the Amman Stream has historically provided socio-cultural and regulatory services for residents through its longitudinal, vertical, and lateral connections with urban form; (2) assess how urban development, and consequently, the culverting of the Amman Stream (in 1967 and 1997) have impacted the stream's regulatory and sociocultural services as well as its connections with urban form; (3) identify traces of the Amman Stream in contemporary Amman's urban form. To achieve these objectives, our methodology combines spatial and qualitative research strategies, namely: spatial analysis using ArcGIS, archival research of historic and contemporary documents and maps, an online survey among Amman's residents, and in situ observations and photography. 


\section{Research Strategies and Data Collection Tactics}

Due to the lack of open-source spatial data for contemporary Amman, Dr. Khirfan purchased from the Royal Jordanian Geographic Center ${ }^{6}$ (RJGC) four sets of data: (i) high resolution scans of three maps that depict Amman's growth between 1946 and 1981; (ii) two sets of high-resolution aerial photographs from 1953 to 1978; (iii) two sets of satellite images from 1992 to 2000 (these four dates align with interventions in the Amman Stream); and (iv) contemporary GIS data for downtown Amman from 2018.

Between January and April 2018, Dr. Khirfan offered a special course on the Amman Stream for ten graduate and senior undergraduate students. Over the span of four months, the PI and the students gathered historic and contemporary documents that focused on the Amman Stream including, among others: studies of the ancient history of Amman during the Classical era and Umayyad period, including maps and studies on water management (Hübner, 1992; MacAdam, 1992; Northedge, 1992a,b,c,d; Arce, 2004, 2008); books like Munif's (1996) memoirs that depicted life in Amman during the 1930s and 1940s and Hacker's (1960) social study of Amman in the 1960s; historic photography (History of Jordan, 2021), and newspaper articles. The course concluded with a fieldtrip to Amman, where the PI and the students conducted in situ observations and photography during April 2018.

Last, we conducted an online survey among Amman's residents who are 18 years of age or older (in both Arabic and English), using Qualtrics. This survey, which consisted of 33 questions, is part of a larger research project that sought to gauge public perceptions in Amman on the role of naturebased solutions in climate change adaptation. We distributed this online survey among the current residents of Amman via social media (e.g., Facebook, Twitter, and Instagram) between 5 and 25 December 2018. In total, 228 respondents participated in this survey (refer to the Supplementary Material for the relevant survey questions).

\section{Data Management and Analysis}

Our spatial data management began by digitizing Amman's town plan elements (i.e., street networks, building footprints, and urban blocks) and natural features using the aerial and satellite imagery from 1953, 1978, 1992, and 2000. We used ArcGIS (a spatial data management and analysis tool) to carry out the digitization within a 150 -m buffer on both sides of the Amman Stream as per its location and flow in the 1953 aerial photo. Given that the 2018 GIS data, obtained from the RJGC, is the most accurate and reliable data, we geo-referenced ${ }^{7}$ each year's aerial/satellite imagery by adding control points using common buildings footprints across the maps. The buffer's long coverage, which followed the stream from Ras al-Ain in the

\footnotetext{
${ }^{6}$ Because spatial data are securitized in Jordan, the RJGC, which is a military unit, is in charge of it.

${ }^{7}$ Geo-referencing is GIS-based practice that transformed the field of cartography by enabling archival documents to become real geographic data (Brovelli and Minghini, 2012).
}

east to the Hashemite Plaza in the west, made accurate georeferencing especially difficult for the later historic layers, when the Amman Stream was completely culverted and lost from the urban landscape. Thus, to ensure accuracy, we geo-referenced the images using ground control points (GCP's) that we added block by block during the digitization process.

Once we completed mapping the town plan elements and natural features for each of the historic layers, we identified the variables through which we sought to assess the impact of culverting on urban form's longitudinal, vertical, and lateral connections (or their traces) to the Amman Stream and on the regulatory and socio-cultural services. Simultaneously, we extracted and organized the relevant data from the online survey. Of the 33 questions, ten questions measured variables relevant to this study. Four of these ten questions directed the respondents (according to their age) to questions that extract their experiences of the Amman Stream over time: before its first phase of culverting in 1967, second phase of culverting in 1997, and the most recent urban design intervention in the Hashemite Plaza completed in 2011 (AbuKhafajah and Al Rabady, 2013). Table 1 summarizes these variables. We used the statistical analysis tools within ArcGIS for the spatial analysis, and Excel software to analyze the survey's findings.

Furthermore, we organized the data obtained from historic and contemporary archives and from the research team's in situ observations and photos. These were categorized based on their relation to the spatial connections between the Amman Stream and urban form and to the regulatory and socio-cultural ecosystem services.

\section{AN URBAN PALIMPSEST: THE ACCRETION OF HISTORIC LAYERS}

Our analysis begins with the historic palimpsest that is Amman's urban form. From its earliest history, whether Iron Age Rabbath Ammon, Classical era Philadelphia, or Umayyad Amman, the settlement form developed around the land relief, namely, the hills surrounding the strath where the Amman Stream flowed and supplied water and fertile soil (Albright, 1925; Northedge, 1992c,d; Al-Abed and Al-Sharif, 2008; Kennedy, 2017). One particular hill, the Citadel Hill (known locally as Jabal al-Qal'a), dominated all others due to the vistas offered by its defensive location, larger size, and long history of human occupation. The Amman Stream itself is a tributary of Seil Al-Zarqa, a larger stream that is part of the Jordan River Watershed (Al-Abed and Al-Sharif, 2008). This stream sprang from the ground at the eastern edge of the strath, at a point called Ras al-Ain (which literally translates to "the source of the stream") and ran westward (Northedge, 1992c,d).

Our historical morphological analysis reveals that, throughout Amman's ancient history, its rulers and residents capitalized on the hilly land relief to emphasize the horizontal, vertical, and lateral connections between their settlement form and the Amman Stream and subsequently, to maximize the stream's regulatory and socio-cultural ecosystem services. Thus, Amman's 
TABLE 1 | The variables we investigated in our spatial analysis using ArcGIS and in the online survey to assess the impacts of the loss of the Amman Stream on its connections to urban form and on its regulatory and socio-cultural ecosystem services.

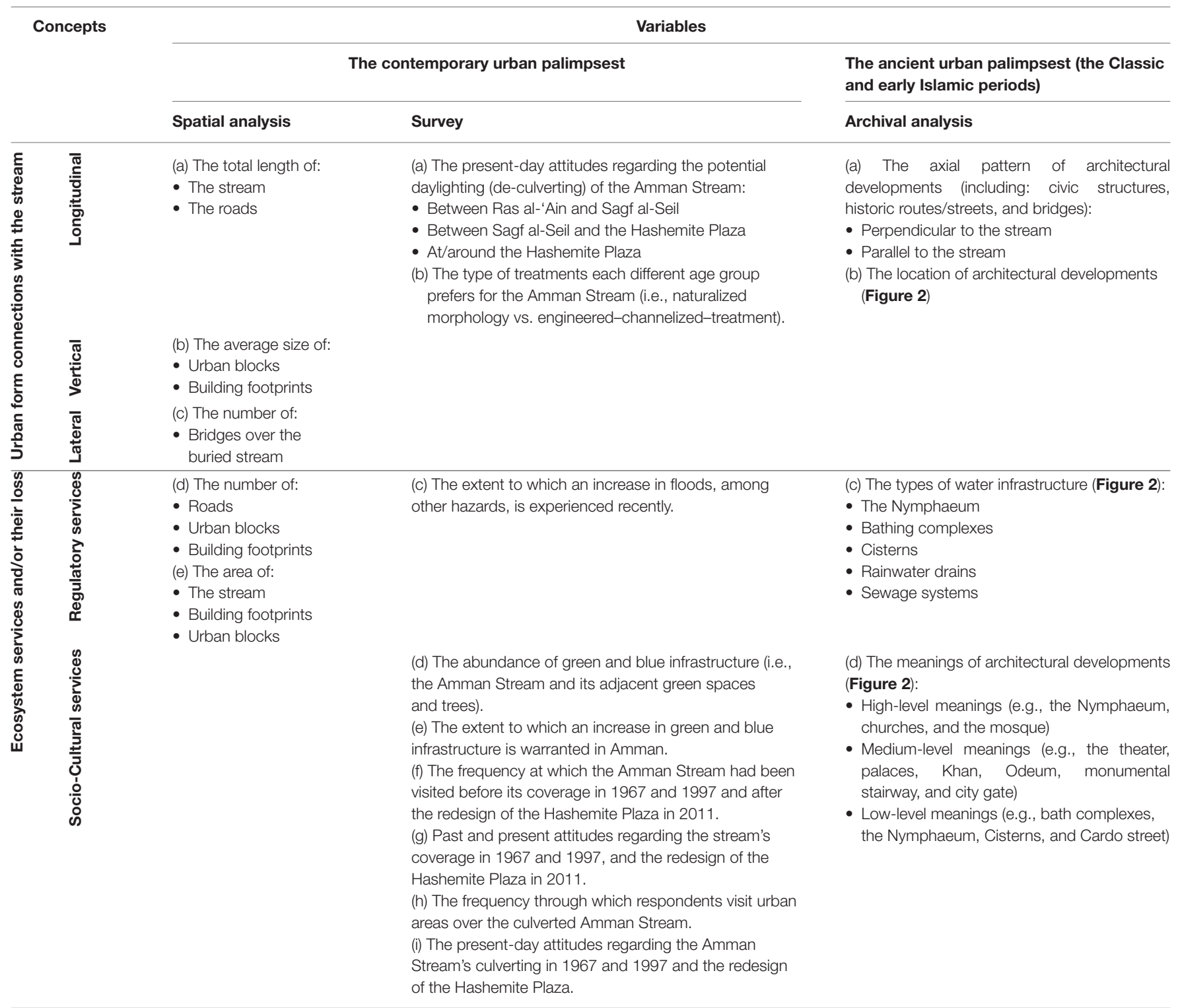

historic urban form maintained a symbiotic relationship with its land relief. Our analysis herewith investigates these relationships during the Classical era and Umayyad period.

The spatial organization of Philadelphia (Classical era Amman), points to an accentuation of the Amman Stream in the urban landscape (Figure 2). This Classical period witnessed a prolific construction of civic structures and urban water management infrastructure that followed a distinct axial pattern that was in harmony with the land relief-i.e., the hills, particularly the Citadel Hill, and the strath where the Amman Stream flowed. These include the main axial thoroughfares namely, the Cardothe colonnaded main street that ran parallel to the Amman Stream, in clear break with the tradition of running northsouth. Similarly, the Documanus, instead of its typical eastsouth orientation, ran in Philadelphia perpendicular to the Cardo and to the Amman Stream while paralleling a smaller stream that is a subsidiary of the Amman Stream. Although typically Classical cities contained two Documani, Amman's land relief precluded that, and in lieu of the second Documanus, a staircase ran simultaneously parallel to the Documanus and perpendicular to the Cardo and to the Amman Stream-establishing a strong connection with the Citadel Hill where prominent structures were built including the Temple of Hercules and a Roman Terrace. Various civic spaces and structures, like the Hellenistic Theater (wrongly dubbed colloquially "the Roman Theatre"), Odeum, Roman Forum (Hellenistic Agora), and public baths (Northedge, 1992a,c) were constructed along the Cardo and the banks of the Amman Stream. Photographic evidence from the nineteenth and early twentieth century indicates that bridges from the Classical era also crossed the 


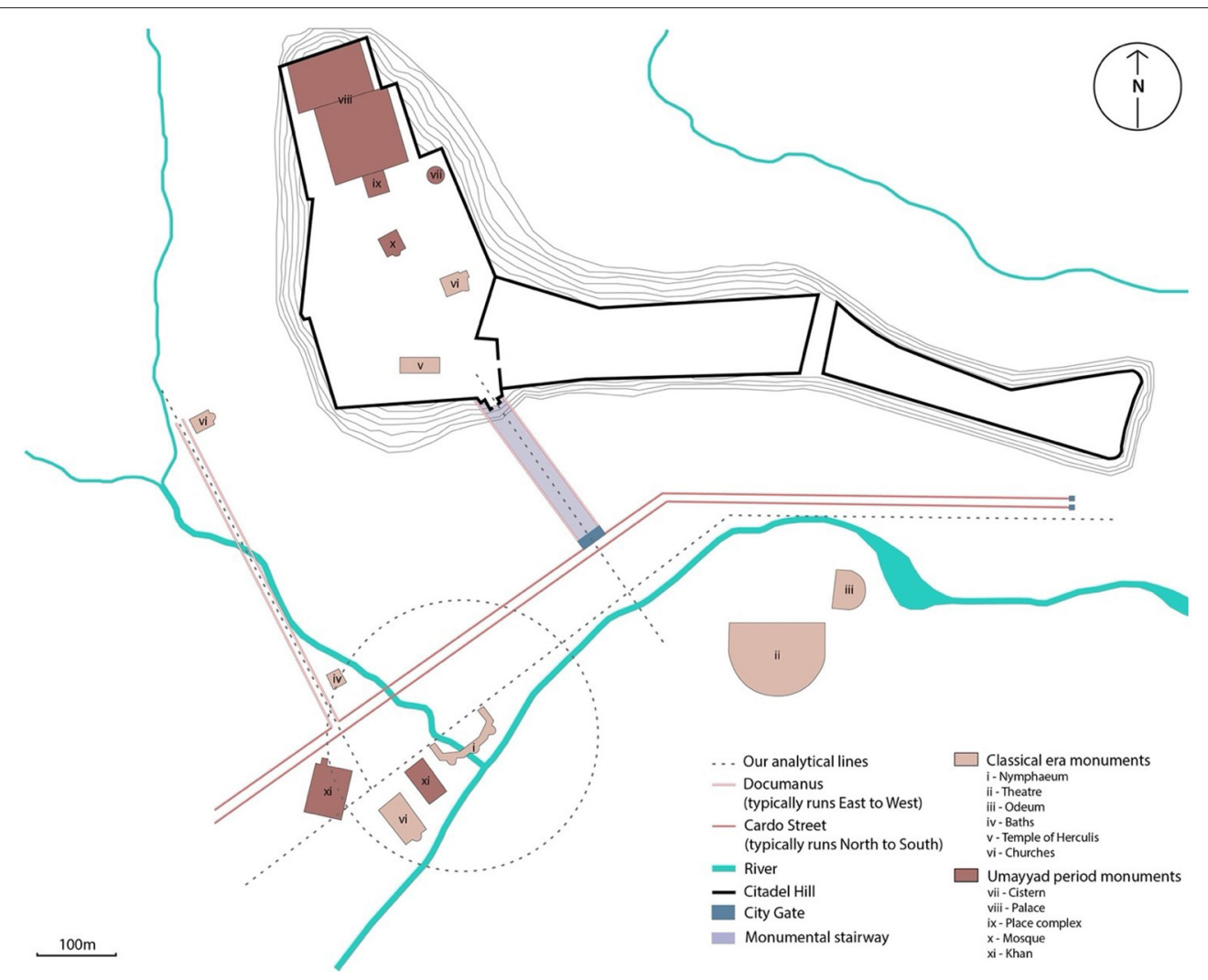

FIGURE 2 | The urban form of Classical era Philadelphia and Umayyad period Amman revered its urban watercourses, primarily the Amman Stream [reproduced from Northedge (1992b) by Sophie Wang under the supervision of Dr. Luna Khirfan-analysis ours].

Amman Stream that would have continued the axiality of the Documanus and the stairway vis-à-vis the Amman Stream and the Cardo (Figure 3A). Collectively, the layout and pattern of the streets and thoroughfares (i.e., stairway) as well as the location and orientation of the civic structures accentuated the vertical, horizontal, and lateral connections with the Amman Stream (Figure 2).

More importantly, a monumental Nymphaeum (in comparison, for example, Gerasa's is miniscule) was positioned at the point where the Amman Stream intersected with its smaller subsidiary in close proximity to the intersection of the Cardo and Documani where the city's baths where also located nearby (Figure 2). As a temple dedicated to the nymphs, the sacred mythological creatures that guarded urban waters (MacDonald, 1986; Yegül and Architectural History Foundation York, 1992), Philadelphia's Nymphaeum held esoteric, high-level meanings. Simultaneously, because it served as a public fountain and an urban landmark where the public gathered for leisure and recreation (through multiple baths, massage, and steaming areas) (Kadhim, 1993), it would have also held quotidian, low-level meanings to the urban population. More importantly, the Nymphaeum also stored and moved water throughout the city (Richard, 2012), hence, served as a significant piece of urban water infrastructure that regulated water distribution. Archaeological evidence points that the water in the nymphaeum would have originated from Ras Al-Ain-the main source of the Amman Stream located nearly 6km to the east. There is evidence that the Romans capitalized on Amman's land relief to design a drainage system that naturally carried the water from the Amman Stream to a storage basin in the Nymphaeum (Yegül and Architectural History Foundation York, 1992; El-Khalili, 2014; Waheeb and AlGhazawi, 2014).

Only a few archaeological remains survived from the Early Christian and Byzantine periods (324-636 AD), probably due to poor construction methods of the time (Haddad et al., 2016). Nevertheless, archaeological evidence points that the numerous Christian monuments (cathedrals, chapels, and churches) built during this period (MacAdam, 1992; Chatford Clark, 2007) continued to abide by the Classical axial patterns of the Cardo and Documanus (see Northedge, 1992c), hence, were either perpendicular or parallel to the Amman Stream. They, therefore, continued the vertical, lateral, and longitudinal connections with the Amman Stream.

Under Umayyad rule during the early Islamic period, Amman, reverting to its Semitic name, prospered once again. The Umayyads built many monuments, mostly atop the Citadel Hill capitalizing on its defensive location while also portraying an image of power and identity. Amman's prosperity during this period emanated largely from its geographic location along the pilgrimage route between Damascus and Mecca (Darb al-Hajj) (Dauphin et al., 2015; Haddad et al., 2016) and by virtue of the Amman Stream which provided water for the traveling 

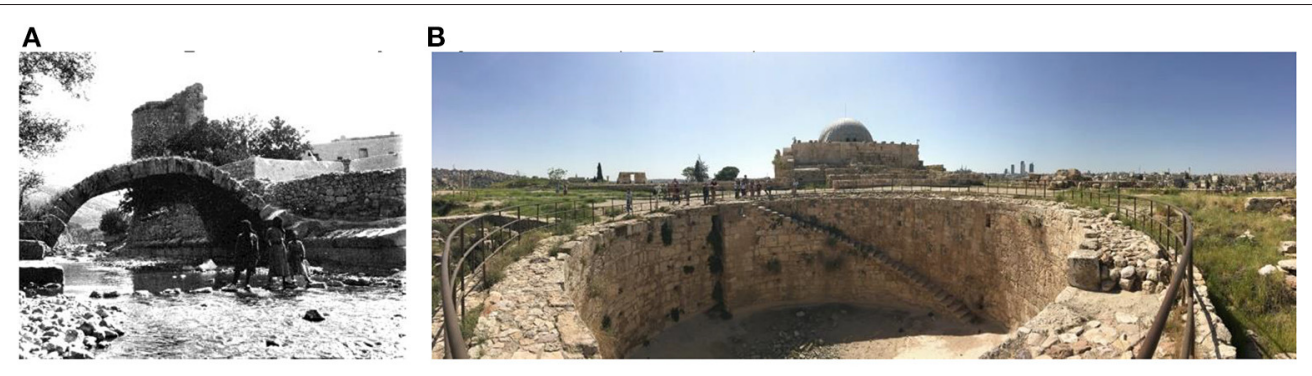

FIGURE 3 | (A) An historic photo from 1900 showing an historic bridge that crossed over the Amman Stream from the Classical era (photo credit: the History of Jordan); (B) The Umayyad period circular cistern atop the Citadel Hill (photo by Dr. Luna Khirfan).

pilgrims (Northedge, 1992b). The new structures atop the Citadel Hill and in the strath continued the Classical period's axial patterns and socio-spatial connections with the stream (see Arce, 2004; Walmsley and Damgaard, 2005). The Umayyads built a mosque near the intersection of the Cardo and Documanus, right by the Amman Stream. But more importantly, akin to the Romans' approach, the Umayyads were cognizant of the value of regulating urban water and invested not only in refurbishing the Classical era water infrastructure, but also, in building new ones. These included numerous rainwater drains, pipes, a sewage system, bathing complexes, and several cisterns (subterranean and open) which were used for collecting and harvesting rainwater (MacAdam, 1992; Northedge, 1992c; Arce, 2004), the most impressive of which is a large circular shaped, open cistern (Figure 3B).

In contrast to ancient Amman's urban morphology that was attentive to the socio-spatial connections with the stream and its regulatory and socio-cultural services, present-day Amman suffers from the consequences of unsustainable water management approaches, which have led to the loss of urban watercourses, including the Amman Stream (Abdulkarim, 2004; Hadadin et al., 2010; Potter et al., 2010). This loss has yielded profound impacts on both the city's urban form, and the stream's regulatory and socio-cultural services, which we discuss in the next sections.

\section{RESULTS: THE CONTEMPORARY URBAN PALIMPSEST}

Our analysis henceforth focuses on the contemporary layers of the urban palimpsest, namely: 1953, 1978, 1992, 2000, and 2018. These dates precede and succeed the two phases when the Amman Stream was culverted: in 1968 and in 1997 and when the Hashemite Plaza was redesigned between 2009 and 2011 (refer to Figure 4). Our analysis draws on our digitization of the maps for these layers using ArcGIS as well as on the online survey results and archival research (both historic and contemporary) to investigate the impacts of the Amman Stream's loss on its regulatory and socio-cultural services. But firstly, we begin with an analysis of the impact of the stream's loss on urban form.

\section{A Lost Stream, a Fragmented Public Realm} Our spatial analysis, using ArcGIS, focused on whether (or not) urban form has changed, and to what extent, with the culverting the Amman Stream and its eventual loss from the urban landscape. We therefore investigate the morphological elements of the town plan: the streets and their networks, the urban blocks, and the building footprints in a 150-m buffer on both sides of the Amman Stream. But we first begin with the change to the Amman Stream itself whose length decreased from $5.77 \mathrm{~km}$ in 1953 to $1.7 \mathrm{~km}$ by 1978 . By 1992 it was reduced to $1.1 \mathrm{~km}$ until it completely disappeared from Amman's landscape by 2000 (refer to Figure 4).

This gradual loss of the Amman Stream was paralleled by an increase in urbanization (Figure 4). The analysis in Figure 5 reveals that the number of town plan elements (i.e., street segments, urban blocks, and building footprints) has increased between 1953 and 2018. This increase, however, has not been consistent over time. While we witness a marked increase in the number of street segments, urban blocks, and building footprints between 1953 and 1978, henceforth, these numbers only increased slightly.

Further analysis reveals that the total length of streets surrounding the Amman Stream has doubled between 1953 and 2018 (increased from 39,579 to $60,013 \mathrm{~m}$ ). The most significant increases in the total length of streets occurred between 1953 and 1992, that is after the first phase of culverting while minimal increase occurred after the second phase of culverting (between 1992 and 2000) (Figure 6).

The total area of building footprints also increased by 63.7\% between 1953 and 2018 (from 289,220 to $473,480^{2} \mathrm{~m}$ ). Interestingly however, the total area of urban blocks actually slightly decreased between 1953 and 2018 (from 1,767,721 to $1,717,011^{2} \mathrm{~m}$ ) (Figure 7). This decrease in the total area of urban blocks also paralleled a slight decrease, since 1953, in the average area of the urban blocks (i.e., the size of urban blocks) and in the average area of the building footprints (i.e., the size of building footprints).

In the next sections, we investigate the implications of these changes in urban form, due to the loss of the Amman Stream, on the urban connections and on the regulatory and socio-cultural ecosystem services.

\section{From Socio-Spatial Connections to Fissures: The Loss of Urban Form Connectivity}

Our spatial analysis of the town plan reveals that as the Amman Stream's length gradually decreased from $5.77 \mathrm{~km}$ in 


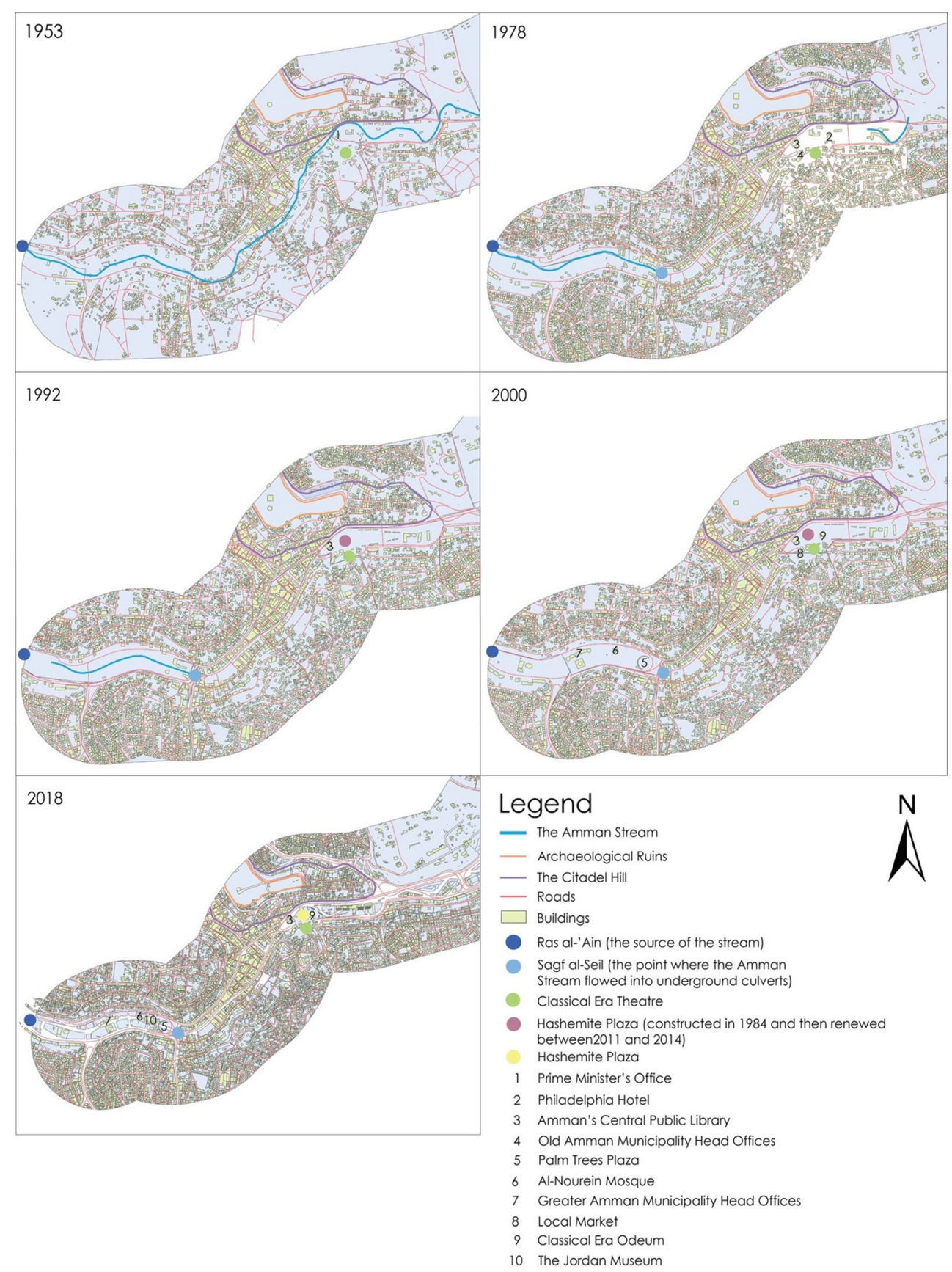

FIGURE 4 | Amman's contemporary urban palimpsest showing changes to the town plan over time with the gradual loss of the Amman Stream (map produced by Sophie Wang under the supervision of Dr. Luna Khirfan).

1953 to zero by 2000 (refer to Figure 4), there have been significant impacts on its longitudinal, lateral, and vertical connections to the surrounding urban form. The longitudinal connections that occurred along the stream's length were gradually eliminated-most prominently visible in the loss of the urban green and blue urban corridor that meandered through the downtown core. In addition to providing a crucial ecosystem, this corridor connected Ras al-Ain where the stream sprang through to the historic core between the Citadel Hill and the Theater (Figure 8A).

The gradual degradation and disappearance of the stream, furthermore, resulted in the loss the lateral connections, i.e., the bridges, that connected both sides of the stream. Amman boasted six historic bridges in 1953 some of which dated back to the Classical era (Figures 3A, 8A). The six bridges were reduced to two by 1978 following the first phase of 


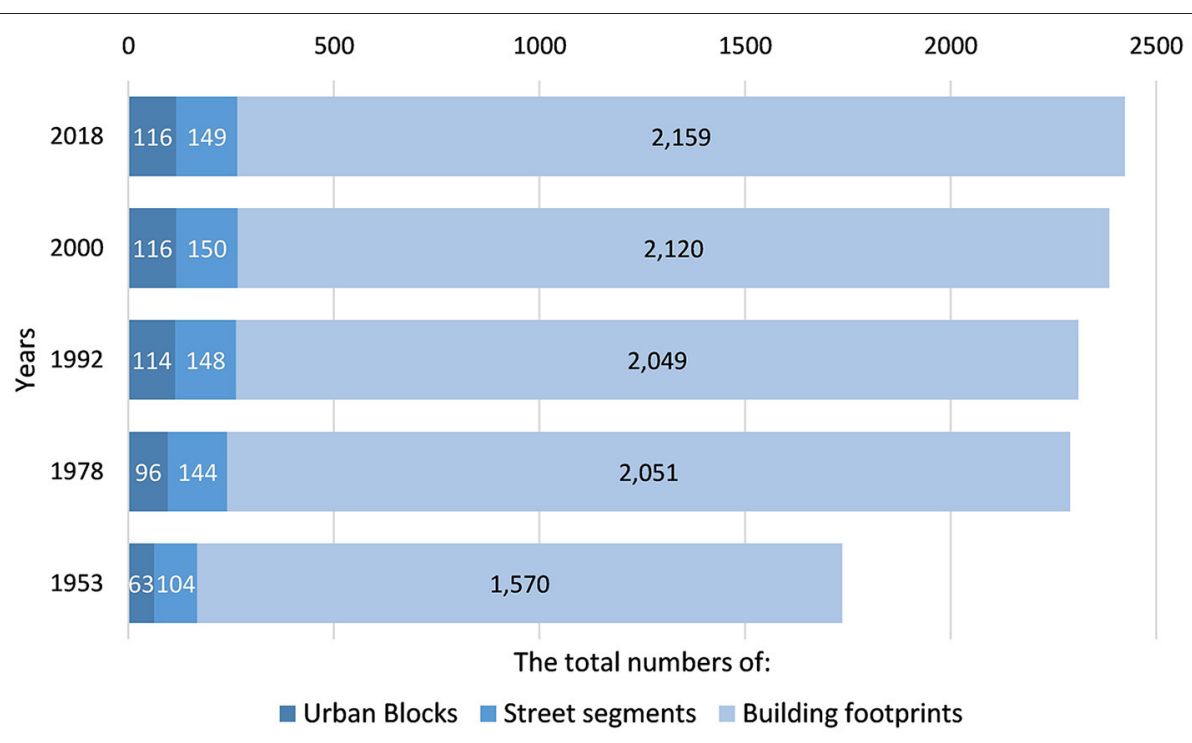

FIGURE 5 | The total number of the town plan elements (urban blocks, street segments, and building footprints) in the 150-meter buffer area during 1953, 1978, 1992, 2000, and 2018.

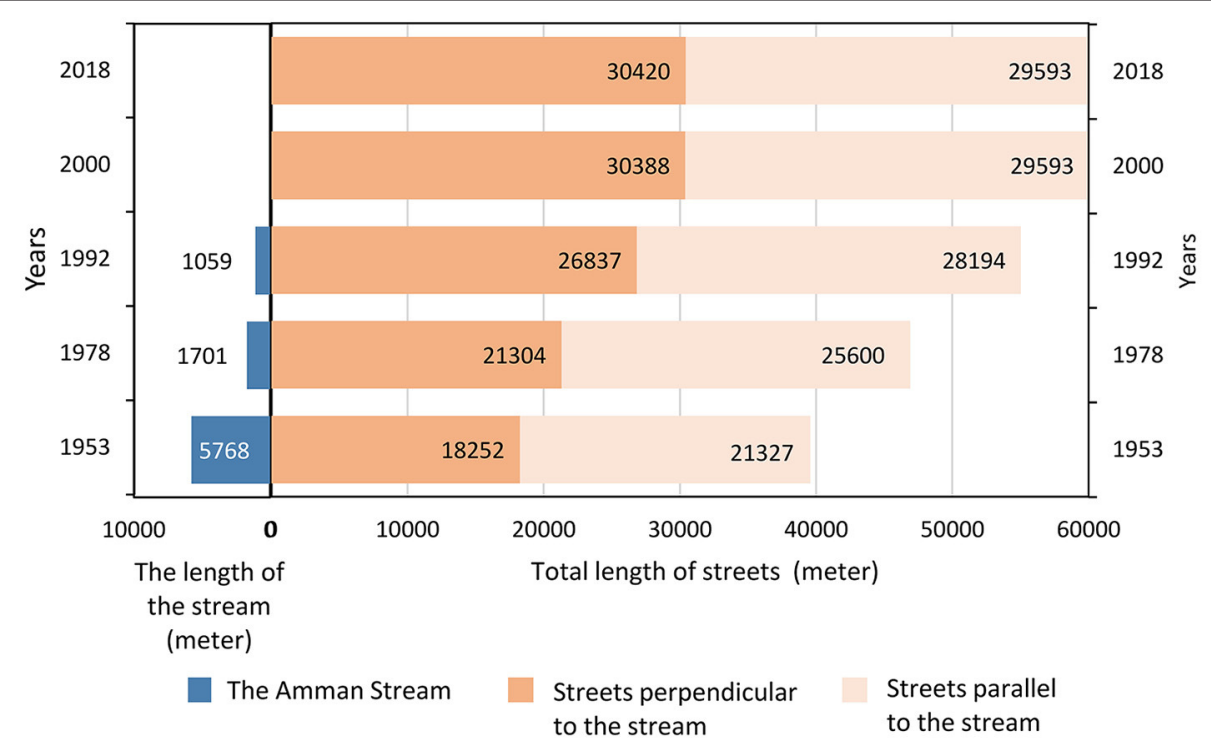

FIGURE 6 | Change over time of the total length of streets in a 150-m buffer on both sides of the Amman Stream.

culverting, but by 1992 only one bridge had remained, which was demolished during the second phase of culverting in 1997. Although the loss of the Amman Stream eliminated the need for bridges, the connections between the two sides of the now lost strath remain weak. This is because the path of the Amman Stream was replaced by busy, predominantly car-oriented roads that exacerbated Amman's already existing socio-economic West-East divide.

The loss of the Amman Stream also led to a loss of many of its associated urban spaces, hence, a loss of the stream's vertical connections (along riverbanks or their upper spaces). The disappearance of the stream's banks from the urban landscape led to a loss of the activities they hosted, whether social and recreational (e.g., picnicking, swimming, and fishing) or economic (e.g., farming, mills, gardening, and animal husbandry) (Figure 8B; see Munif, 1996).

Despite the elimination of the longitudinal, lateral, and vertical connections, we can still observe their traces in the urban form. Indeed, the new road network runs parallel to the lost stream, while the streets perpendicular to them follow the traces of the ancient bridges (Figure 4). Thus, essentially, despite the loss of the Amman Stream, it continued to play a role in shaping contemporary urban form. 


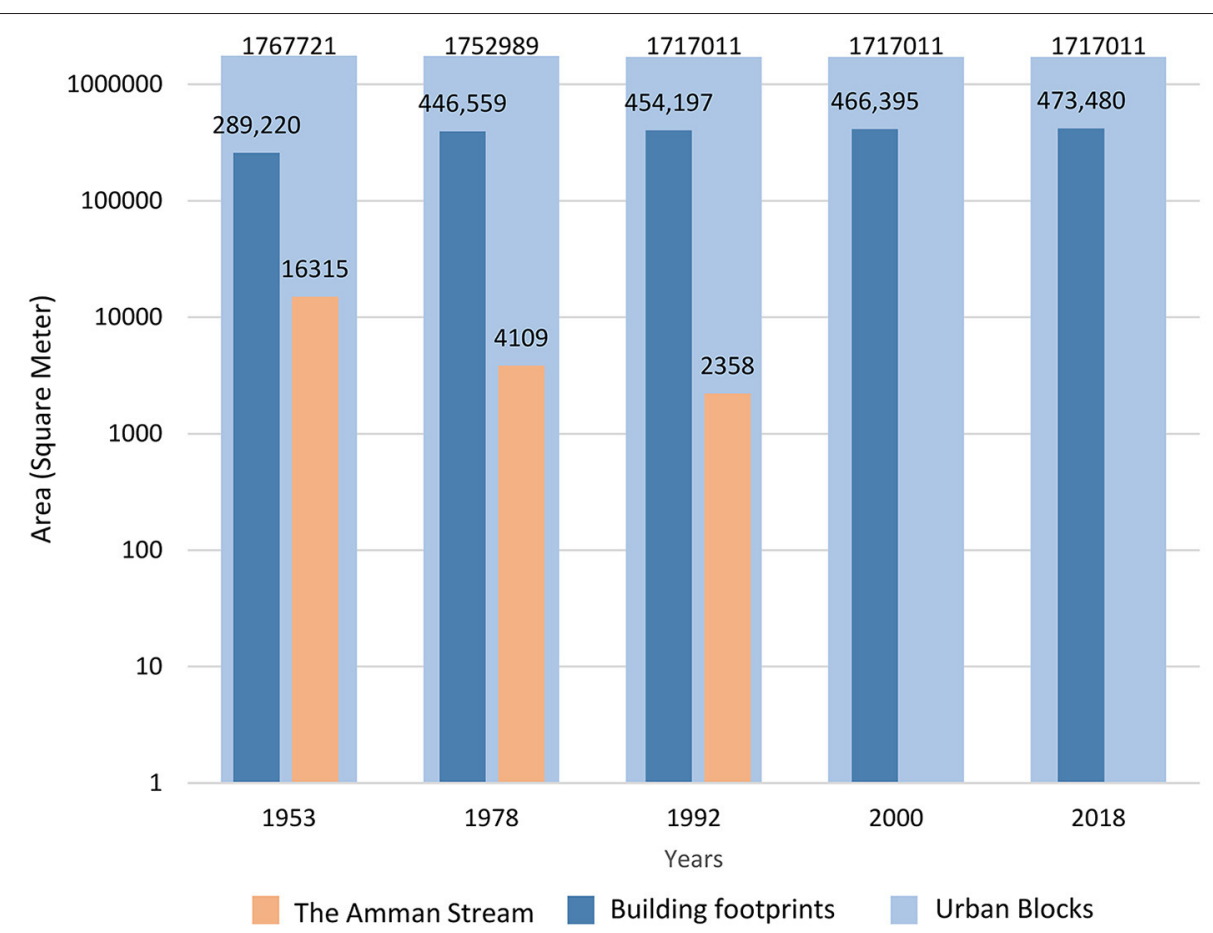

FIGURE 7 | The total area of the Amman Stream, the building footprints, and the urban blocks during the years 1953, 1978, 1992, 2000, and 2018 (150-m buffer on both sides of the Amman Stream).
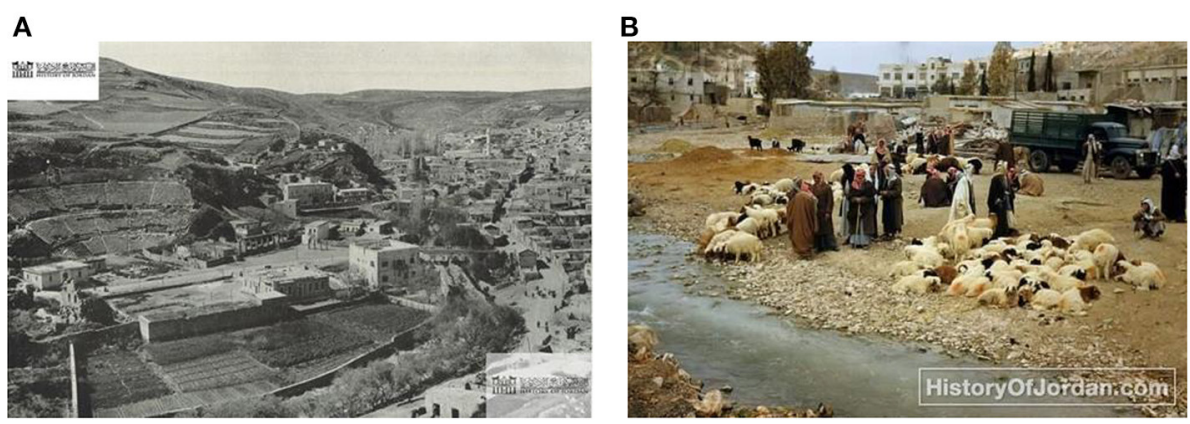

FIGURE 8 | (A) The Amman Stream in 1944 when it provided a crucial green-blue corridor surrounded by farms, gardens, and a cattle market. A bridge is also visible (photo credit: the History of Jordan); (B) An historic photo from 1950 showing the cattle market by the Amman Stream (photo credit: the History of Jordan).

\section{From an Urban Blue-Green Corridor to an Urban Desert: The Loss of Regulatory Services}

The increase, since 1953, in the number of building footprints and roads, in the total area of building footprints and, most significantly, in the total lengths of streets entails an increase in impervious surfaces and, by consequence, an increase in rainwater runoff. Given Amman's land relief, this runoff spilled over the hills toward the strath where the Amman Stream once flowed but which now consists of impervious surfaces. Even before any culverting of the Amman Stream, rainwater runoff caused several floods mentioned in Abdul Rahman Munif's memoir "Story of a City: A Childhood in Amman" and documented in historic photos (Munif, 1996) (Figure 9). Eventually, the runoff and the continuous floods degraded the stream's ecosystem, leading to its pollution, and consequently, to its partial and finally complete culverting in 1967 and 1997 (see Hacker, 1960; Sakr, 2013; Peck and Khirfan, 2021). If anything, however, this eradication of the Amman Stream from the urban form, exacerbated the flooding events.

Especially nowadays with the increased intensity and frequency of extreme rainfall events associated with global climate change, the adaptive capacity of Amman's urban form to the increased precipitation rates has significantly decreased. Surely, several excessive rainfall events occurred almost in every year the last decade (such as in 2015, 2018, and 2020) during 


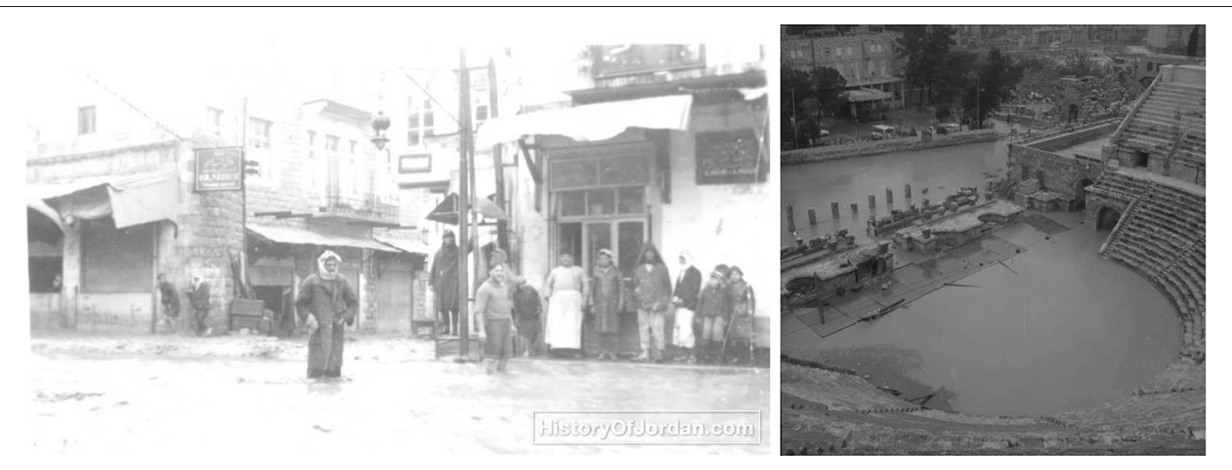

FIGURE 9 | A composite of two photos showing two flooding events in downtown Amman from 1938 and an undated one believed to be during the 1960 s (photos credit: the History of Jordan).

which rainwater runoff accumulated from the surrounding hills over the Amman Stream's former strath, now impervious surfaces, to flood the downtown core. Newspaper reports clearly document how, in the past decade, Amman's residents have suffered significant loss of life and livelihoods-see for example: (Noghai, 2015; Namrouqa, 2018; Al Nawas, 2020). The findings from our survey reveal that of the 126 respondents who answered a question about floods events, 83 said that they noticed an increase in the intensity and frequency of floods, among other climatic hazards. Also, 67 respondents reported that they observed an increased frequency of rainstorms in recent years due to the global climate change.

\section{From Reverence to Nostalgia: The Loss of Socio-Cultural Services}

We also sought to investigate the impacts of the loss of the Amman Stream on its meanings by considering Rapoport's (1988, 1990) lower-, medium-, and higher-level meanings as discussed earlier.

The Amman Stream and its adjacent green spaces once supported an array of quotidian activities that are associated with lower-level meanings. Prior to its first phase of culverting in 1967, the stream's riverbanks served as public spaces where, according to Munif's memoir (1996), Amman's residents gathered for social and recreational activities like fishing, swimming, and picnicking. Munif also refers to economic activities along the stream's banks like the city's two mills (named after two local families: Mufti and Malhas), tanning industries, agricultural activities, and a local cattle market (Figure 8B) (Ibid.). The stream's culverting, restricted, and in some instances eliminated, many of these activities. This finding is confirmed by our survey results that clearly show the loss of interest among Amman's residents, over time, to visit the urban spaces around and over the now culverted stream. Of the 132 who responded to questions around on this subject, only 34 said they visit the Hashemite Plaza (in front of the Classical era Theater, at the western end of the culverted stream), 49 said they frequent the area between the Hashemite Plaza and Sagf el-Seil, while 46 said they frequent the area between Sagf al-Seil and Ras al-'Ain (at the eastern end by the Greater Amman Municipality's Head Offices where the stream sprang) (Figure 10).
Such contemporary loss of interest in visiting Amman's downtown core where the Amman Stream used to flow, are also rooted in the contemporary configuration of urban form over the buried stream. This configuration composes of predominantly hard surfaced urban public spaces that lack green and/or blue cover and which are sandwiched between busy, car-oriented roads, hence, preclude walkability (Figure 11). Indeed, among the 228 survey respondents, a significant majority believes that there is, in Amman, a lack of: trees ( 74 respondents), green spaces (132 respondents), and urban water features (169 respondents). In addition, among the 228 respondents, an overwhelming majority agrees that an increase in trees (198 respondents), green spaces (213 respondents), and urban water features (195 respondents) would contribute positively to their quality of life (see Figure 12).

Although the Amman Stream disappeared, its mediumlevel meanings remain impactful in Amman's culture, spatial arrangement, and urban design. Culturally, the Amman Stream remains alive in the urban nomenclature through enduring terms like Ras al-Ain (i.e., the source of the stream) and Sagf elSeil (i.e., the point where the stream flowed into culverts after the first phase of culverting in 1967)-terms that continue to be a part of the urban collective memory. Spatially, traces of the Amman Stream persist in the urban landscape (Figure 13). Indeed, as mentioned in the previous sections, the contemporary street network follows the path of the strath where the Amman Stream used to flow. Furthermore, still visible on Amman's urban palimpsest are traces of the several historical monuments that dotted the banks of the Amman Stream including the Classical era Theater, the Odeum, parts of the Roman Forum (Hellenistic Agora), and the Nymphaeum. The alignment of contemporary civic structures along the stream's path continued even after its loss, the most significant of which is the new Greater Amman Municipality Head Office, the Jordan Museum, al-Nourein Mosque, and the Palms Plaza-all of which are located at Ras al-Ain, the point where the Amman Stream sprung from the ground. On the western end, there is the Hashemite Plaza, Amman's Public Library, and the Folklore Museum. Last, the urban design features at the east and the west edges of where the Amman Stream used to flow include elements that echo the stream's path. For example, to the east at Ras al-Ain, 


\section{Q. Approximately, at present, how frequently do you visit:}

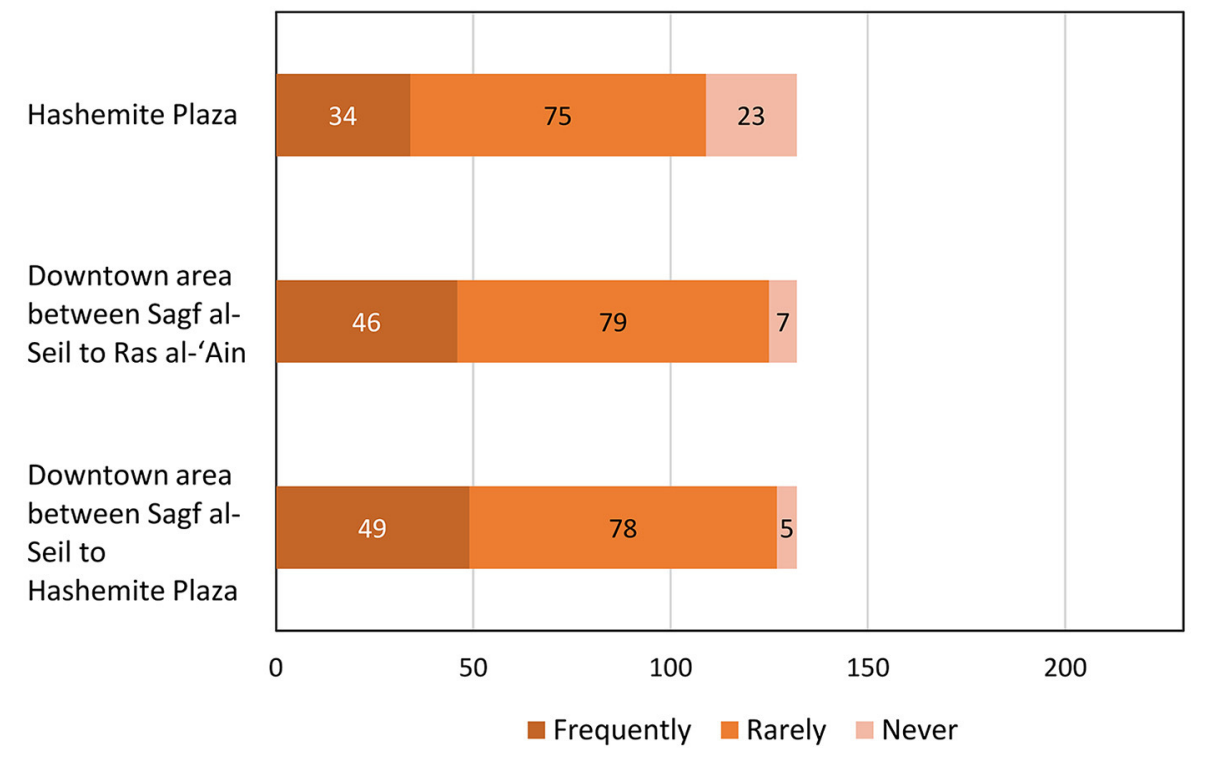

FIGURE 10 | The survey respondents' frequency of visiting Amman's downtown areas that spread over the culverted stream.
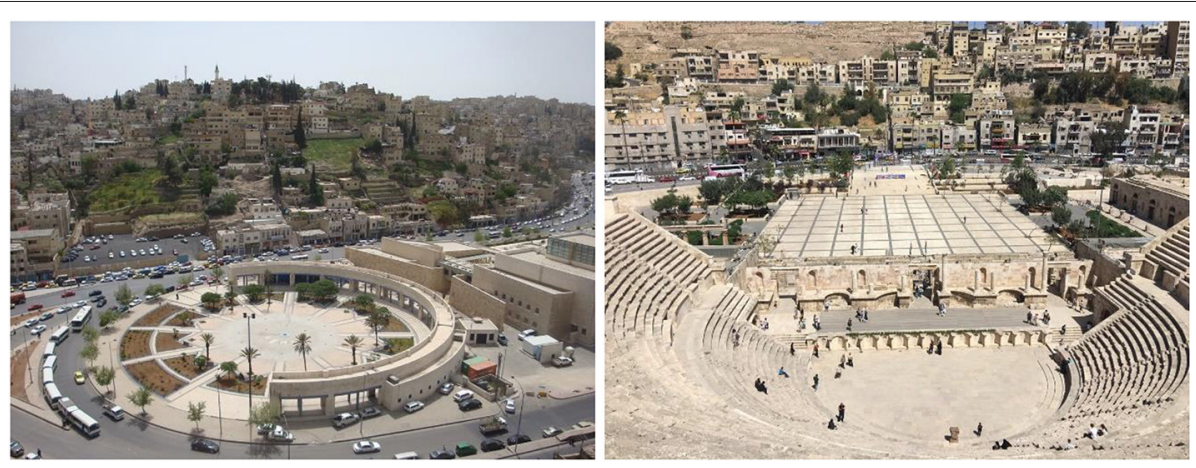

FIGURE 11 | The two plazas at both edges of the Amman Stream (the Palms Plaza at Ras al-'Ain and the Hashemite Plaza by the Classical era Theater) are predominantly hard surfaces surrounded by car-oriented roads (photos by Dr. Luna Khirfan).

there are channels in the ground that symbolize, in nostalgic gestures, the Amman Stream on the grounds of the municipal headquarters while at the west end, by the Hashemite Plaza and the Odeum, there are coloured tiles that trace the stream's path (see Figure 14). Unfortunately, however, the Amman Stream's esoteric, higher-level meanings seem to be lost forever from the urban form-an incongruity with Amman's severe water scarcity.

\section{DISCUSSION: CAN THERE BE REVIVAL AFTER LOSS?}

The lengthy interruption in Amman's urbanization since around $750 \mathrm{AD}$ until the early twentieth century allows us to draw comparisons in the town plan (street networks, urban blocks, and building footprints) between the historic and contemporary periods with regards to urban water in general and the Amman Stream in particular. Archaeological evidence from the Classical era (Hellenistic, Roman, and Byzantine) when Amman was known as Philadelphia and from the early Islamic, i.e., Umayyad, period clearly indicates how urban watercourses played a distinct and crucial role in urban development. The waters of the Amman Stream were venerated through temples and civic monuments like the Nymphaeum and the Baths that also served as water management infrastructure. There were also cisterns (both subterranean and open) that harvested rainwater and, most probably, connected to the Amman Stream. There was also an array of bridges that connected both sides of the Amman Stream.

The contemporary attitudes toward the Amman Stream stand in sharp contrast to its historic reverence and to the prudence in developing water management infrastructure. Since the 1960s, fluvial land reclamation led to the gradual loss 


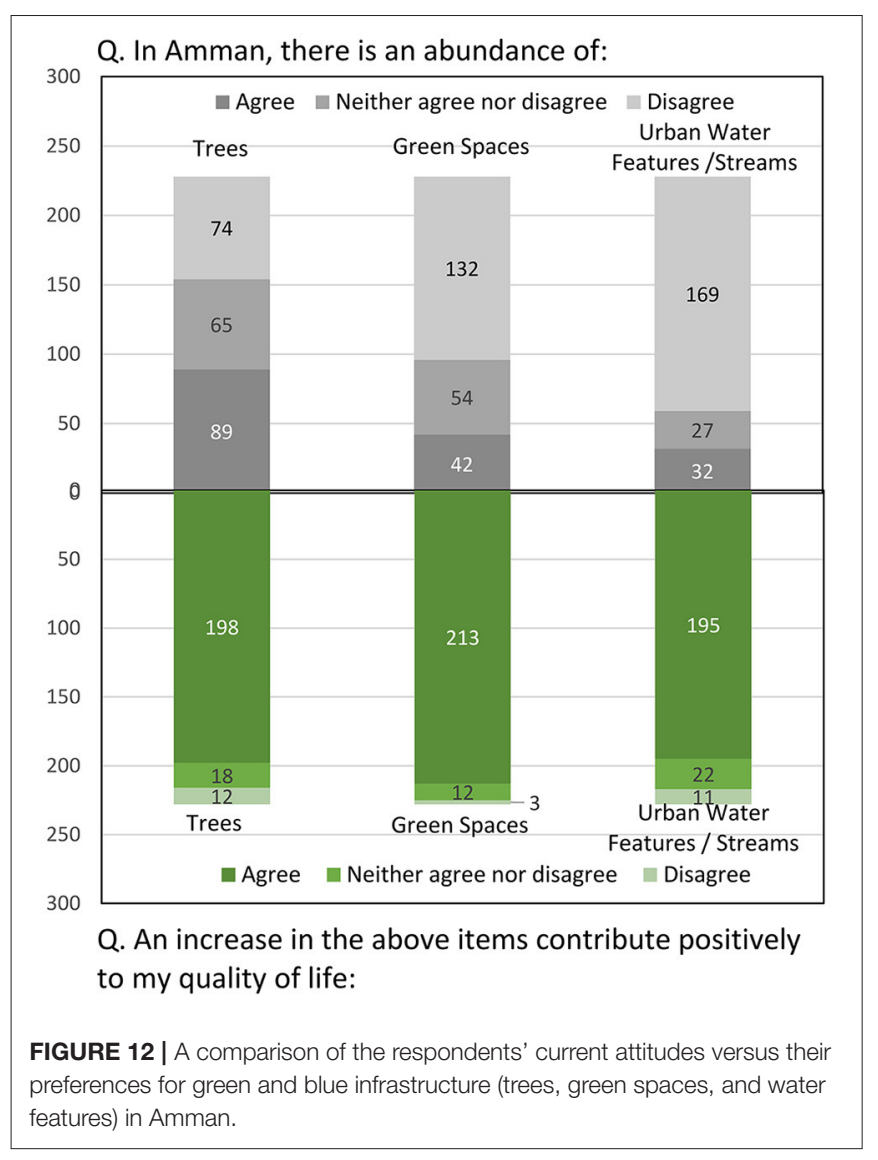

of the Amman Stream triggered by the spasmed population increase due to regional political instability. Consequently, the stream diminished from a $5.77 \mathrm{~km}$ stretch in Amman's downtown core in the 1950 s to a $1.70 \mathrm{~km}$ stretch by 1975 to being completely lost by 2000 (see Figure 4 ). Such loss also negatively impacted the stream's longitudinal, vertical, and lateral connections throughout the urban landscape and the regulatory and sociocultural ecosystem services it provided.

Our analysis of the urban form, specifically, of the town plan elements around the Amman Stream (street networks, urban blocks, and building footprints) reveals that while the building footprints and the urban blocks stabilized after 1978, the streets and street networks almost doubled in numbers and total areameaning, the total area of impervious surfaces doubled in the downtown core. Moreover, the street network's configuration is such that it not only precludes pedestrian movement, but also, demarcates social disparities between an affluent West and an impoverished East Amman. This is because when the Amman Stream and its green corridor were lost, they were replaced by car-oriented roads and impervious, hard surfaces. Moreover, the stream's loss entailed losing the six bridges, which when replaced with the car-oriented roads eliminated the lateral connections across the strath, hence, precluded socio-economic and cultural connections among Amman's residents on both sides while cementing their East-West divide (on Amman's EastWest disparities see Gobster and Westphal, 2004; Angel et al.,
2012). Last, the loss of the Amman Stream led to a loss of the social and economic activities that historically took place along its banks, hence, led to a loss of the vertical connections (Searns, 1995; Kondolf and Yang, 2008) also see (Munif, 1996).

In addition to the detrimental impacts of the Amman Stream's loss on urban connectivity and on socio-cultural services, our findings also point to the calamitous impacts in terms of regulatory services. Culverting streams and urban watercourses is bound to increase the risk of flooding (see Wild et al., 2019; Sohn et al., 2020). Surely, the now frequent floods from rainwater runoff in recent years in Amman's downtown, particularly along the strath where the Amman Stream used to flow, have claimed lives and have caused significant damages to property and livelihoods. As extreme weather events, that are associated with climate change, increase in their frequency and intensity, the risk of flooding in Amman's downtown is bound to increase. The residents of Amman, in their responses to our survey, were not optimistic. So, what can be done?

Our analysis of the urban form reveals that for the most part, the strath is currently predominantly roads with very few buildings constructed over the culverted Amman Stream (see Figure 13). Although this proliferation of impervious surfaces and car-oriented roads negatively impacts regulatory ecosystem services and urban connectivity, it nevertheless means that there are relatively few building footprints over the culverted stream. This opens the door for the possibility of daylighting (de-culverting) the Amman Stream to restore it to the urban landscape. Stream daylighting is a practice that is being increasingly implemented in various cities around the world, such as Zurich and Seoul (Khirfan et al., 2020b,c,d). Daylighting the Amman Stream would reinstate its regulatory ecosystem services by assisting stormwater management, contributing to the harvesting of rainwater runoff in a water insecure city, and in replenishing the River Jordan Watershed. It, furthermore, through restoring the urban spaces along and around the Amman Stream, would reinstate the stream's socio-cultural services and morphological connections, increase Amman residents' interactions with nature, which can further enhance their adaptive capacity to climatic impacts such as urban heat island (UHI), and simultaneously, elevate their quality of life. Not only does the daylighting of the Amman Stream warrant minimum urban morphological intervention, but it is also supported by the public. Certainly, most respondents to our survey support the daylighting of the Amman Stream. Of the 132 respondents who answered a question about daylighting various segments of the Amman Stream: 55 respondents agreed that the Amman Stream should be daylighted from Sagf alSeil to the Hashemite Plaza (the segment that was culverted during the first phase in 1967), 59 agreed that it should be daylighted between Ras al-Ain to Sagf al-Seil (the segment that was culverted during the first phase in 1997), while 54 agreed that it should be daylighted at Hashemite Plaza (the segment that was culverted after 1978 and redesigned between 2009 and 2011). Interestingly however, when asked about their preferred treatment for the Amman Stream once daylighted, of the 129 respondents who answered this question, 100 preferred a channelized architectural treatment while only 


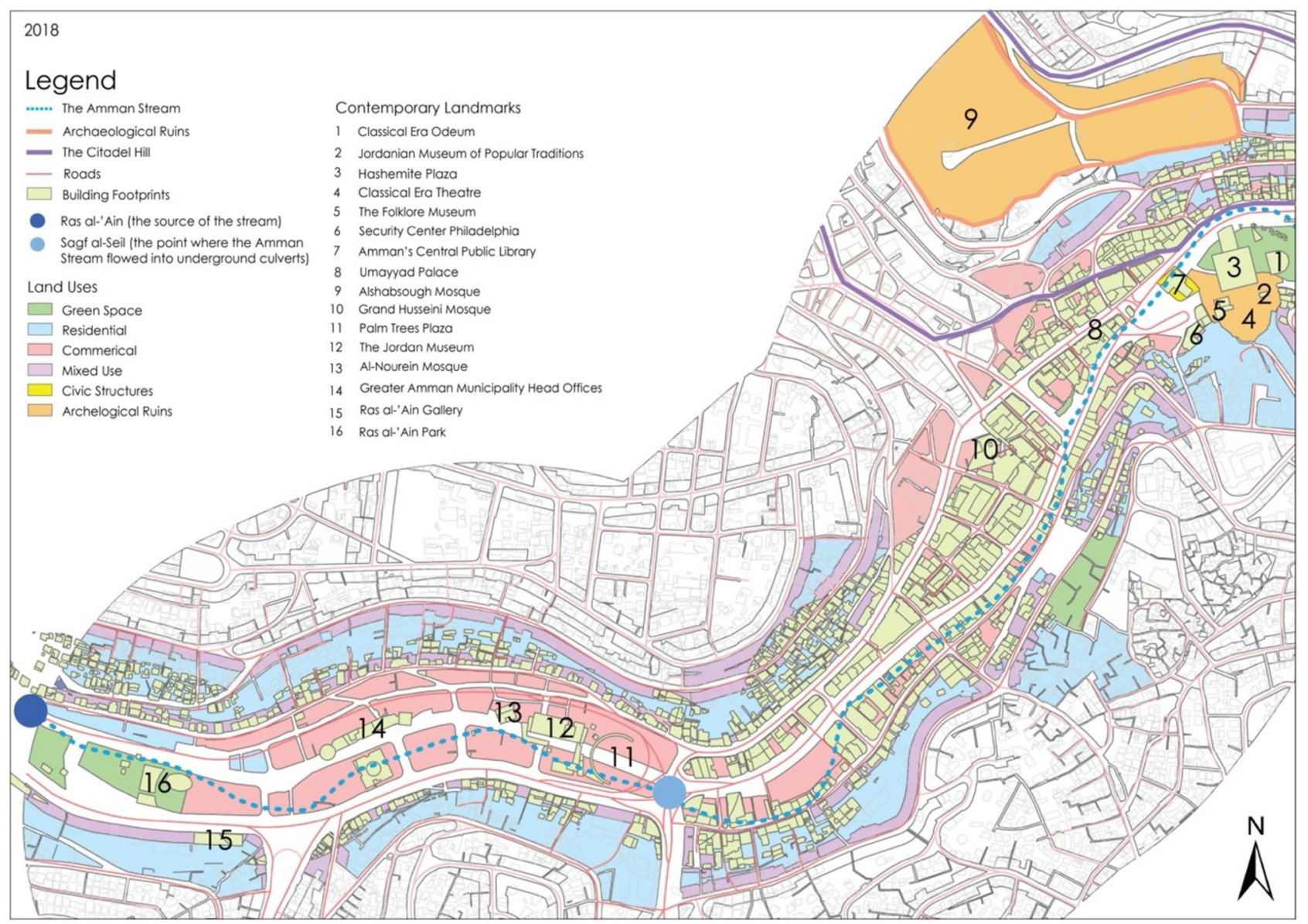

FIGURE 13 | The spatial traces of the Amman Stream persist in the urban landscape (map produced by Sophie Wang under the supervision of Dr. Luna Khirfan).

29 preferred a naturalized one that recreates the stream's original geomorphology. Since such an architectural treatment could potentially strengthen the horizontal, lateral, and vertical connections through design that includes walkable paths along the daylighted stream, pedestrian bridges over it, and social spaces along and around it, the respondents' perspective indicates a need for such social spaces.

Amman's rapid population growth, when combined with unsustainable urban development and the mismanagement of water resources placed significant pressures on water resources which culminated in the lowering of the water table in the surrounding aquifers, which exacerbated perpetual water shortages and land infertility (Abdulkarim, 2004; Hadadin et al., 2010; Potter et al., 2010; Schyns et al., 2015; Weinthal et al., 2015). Accordingly, although Jordan includes 15 individual watersheds, it is nevertheless amongst the 10th poorest countries in water supply and availability (Abu-Sharar, 2006). Thus, as Jordan's capital and most populous city, Amman's water insecurity is extremely precarious. Daylighting and restoring the Amman Stream will generate cascading positive impacts at the local and regional scales. Locally, a daylighted Amman Stream will facilitate rainwater harvesting and stormwater management by collecting the runoff from the hillsides, hence, will enhance the city's resilience to climatic hazards and to water insecurity. Regionally, a daylighted Amman Stream will flow in, and replenish the Zarqa River Basin, which consequently replenishes the Jordan River Watershed. Table 2 summarizes this study's main tactical outcomes and their implications for future policies and plans.

Our study is, indeed, not without limitations that mostly pertain to the restricted access to records historical and contemporary. For example, the lack of reliable historical records of the types of vegetation and the nature of the historic wetlands rendered it impossible for us to analyze the change in the ecology over time. Furthermore, the restricted access to spatial data limited, significantly, the type and nature of spatial analyses. Therefore, our analysis, to a large extent, is qualitative and constitutes an early start to larger quantitative analysis that will incorporate statistical modeling for finding correlations between the loss of Amman Stream and regulatory/sociocultural ecosystem services. Last, it is essential to underscore that our analysis does not account for geopolitical or financial 

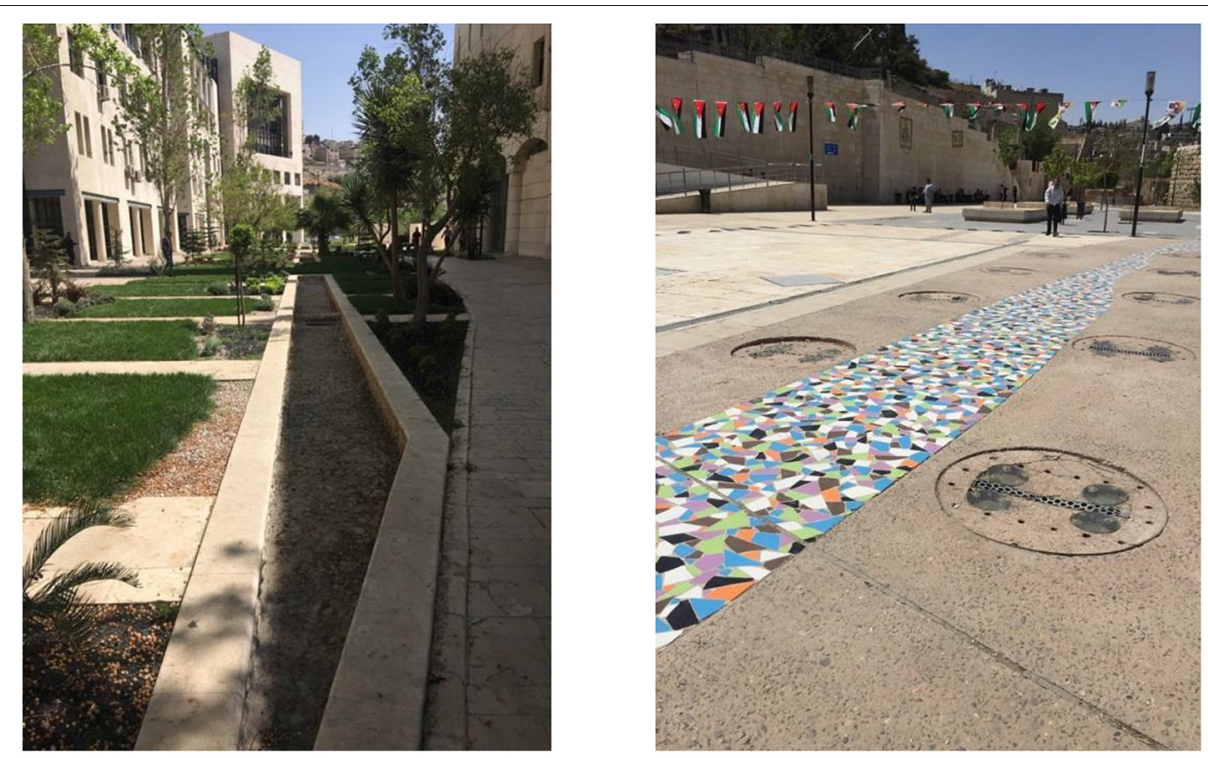

FIGURE 14 | Urban design elements that symbolize the Amman Stream, namely channels by the municipal headquarters at Ras al-'Ain to the east (left) and coloured tiles in the Hashemite Plaza's extension to the west (right) (photos by Dr. Luna Khirfan).

considerations with regards to the daylighting (de-culverting) of the Amman Stream.

\section{CONCLUSION: POURING NEW LIFE INTO LOST STREAMS}

This study's findings assert that the significance of the connections between a city, Amman in this case, and its stream. When fluvial land reclamation ensues in culverting urban streams and their loss from the urban landscape, this leads to negative repercussions on these stream's ecosystems and the services they provide as well as on the form of the urban settlement. Thus far, there is a dearth of studies that connect the culverting of urban streams to urban form in general, and in particular, in cities located in water-scarce hot and dry regions in developing countries. By focusing on Amman, Jordan's capital, this study sought to address such a dearth. Specifically, we focused on the change, over time, in Amman's urban form as the Amman Stream was gradually lost to urbanization. Our analysis investigated how the Amman Stream, through its longitudinal, vertical, and lateral connections with urban form, has historically provided socio-cultural and regulatory ecosystem services and consequently, how the stream's culverting led to a loss of these connections and of ecosystem services.

Our findings also reveal a stark contrast between the historic and contemporary attitudes toward the Amman Stream. From reverence and water-specific infrastructure (e.g., open and underground cisterns) that capitalized on its regulatory services in the Classical era (Hellenistic, Roman, and Byzantine) and the early Islamic period, to a complete absence of such infrastructure from the contemporary urban landscape. Moreover, the Amman Stream played a remarkable role in the development of urban form, primarily due to its associated socio-cultural ecosystem services. Surely, throughout history, several civic structures, like the Nymphaeum, public Baths, Theater, and several churches and mosques were built along a Cardo that, instead of its typical north-south orientation, followed the stream's route. A series of bridges connected both sides of the stream. Once lost from contemporary Amman's urban landscape (partially in 1967, then fully in 1997), the Amman Stream was replaced mostly by caroriented roads that ran through the strath. These roads almost match in their configuration the stream's original catchment area-apparently, tracing its path in the urban palimpsest. These traces are further augmented with the several contemporary civic structures that dot the stream's path including, the Greater Amman Municipality Head Offices, the Jordan Museum, the Central Public Library, and even the Royal Raghadan Palaces (at the far east side) (Figure 13). The stream's omnipresence in the urban palimpsest, however, does not entail a continuation of the regulatory services it offered, including its benefits for managing and discharging the excess rainwater, nor its socio-cultural services, including its esoteric, spatial, and socio-economic and cultural meanings-all of which, along with the longitudinal, vertical, and lateral connections, have completely been eradicated from Amman's urban form. In particular, the loss of connectivity, exacerbated Amman's East-West socio-economic fissure.

The increase in extreme weather events that are associated with climate change, especially in Amman's case extreme rainfall and extreme drought, combined with the increased social vulnerabilities (due to the influx of refugees and existing water scarcity), the need for nature-based solutions that restore lost ecosystems and their services as well as their connections to urban form becomes essential. Hence, our recommendations to daylight and restore the Amman Stream to the urban landscape. This stream's daylighting, as per our town-plan analysis, will 
TABLE 2 | A summary of this study's tactical findings and their implications for policies and plans.

\section{Tactical planning outcomes}

Implications for future policies \& plans
Between 1953 and 2000, the Amman Stream was gradually reduced from a $5.77 \mathrm{~km}$ stretch to, effectively, zero (total loss) as a result of the city's urbanization and ongoing development.

There is a stark contrast between historical and contemporary attitudes toward the Amman Stream. While historic Amman benefited from infrastructure that capitalized on the regulatory services of the Amman Stream, the contemporary unsustainable approaches of urban development led to the complete loss of the stream.

Culverting the Amman Stream led to the complete loss of its socio-cultural and regulatory ecosystem services and its connections with urban form.
Amman's future policies and plans should take ecosystems into account. Historic documents that discuss the past conditions of ecosystems should be made public and available to academics and researchers as well as to local communities Similarly, there is a need to document the current conditions of ecosystems and to invest in ecosystem rehabilitation.

The narrative of urban development in Amman warrants a paradigm shift from a focus on architectural landmarks and gray infrastructure, to one that centers on blue-green infrastructure.

Furthermore, there is a need for reflective planning approaches that take "evaluations" more seriously and where urban planners are able and willing to learn not only from past mistakes, but also from the historic's and the vernacular's best practices.

The Greater Amman Municipality (GAM) must invest in studies, policies, and plans that document all ecosystems within the city of Amman, including street trees; lawns; parks; urban forests; cultivated land; wetlands; lakes; sea; and streams (Bolund and Hunhammar, 1999).

There is also a need to understand the four groups of ecosystem services-i.e., the benefits humans in/directly perceive from natural ecosystems: provisioning, supporting, regulating, and cultural (Costanza et al., 1997; Wallace, 2007; Yeakley et al., 2016).

There is a significant increase in the number of car-oriented streets over the buried stream combined with a loss of socio-cultural activities that historically took place along, adjacent, and across the stream banks, have collectively precluded pedestrian movements. These pedestrian-unfriendly urban spaces reduced connections between Amman residents on both sides of the buried stream, exacerbating the East-West divide in this city.

A significant increase in the area of impervious surfaces, which can increase the risk of floods with the increase in intensity and frequency of precipitations due to climate change.

The Greater Amman Municipality (GAM) must reconsider its planning approach that the expense of blue-green infrastructure and pedestrian-friendly spaces (Abu-Khafajah Amman. There is a dire need for urban design that centers on pedestrian-friendly experiences and on modes of movement other than the private automobile.

Climate change should become central to planning in Amman. Thus far, climate change is absent from the planning narrative. There is a dire need to plan for:

(1) Mitigation (decreasing greenhouse gas emissions) by planning for walkability, cycling, prioritizes auto-oriented development, gray infrastructure, and impervious hard surfaces at and Al Rabady, 2013). Walkability and cycling remain absent from the planning narrative in and public transit as well as incorporating blue-green infrastructure in the urban landscape (carbon sinks);

(2) Adaptation (minimizing the negative impacts of climatic hazards and capitalizing on the potential benefits of a changing climate). This study highlighted flood hazards, which can be converted into a benefit in a country where water scarcity is paramount. Excess rainwater can be harvested and used in agriculture and other uses. There is also a need to study and plan for other negative impacts of climate change like the urban heat island effect (UHI).

Despite the total eradication of the Amman Stream, our findings reveal its continuous impact on urban development through buildings and streets that follow the stream's route.

The Amman Stream remains alive in the collective memory of Amman's residents and in its urban landscape. Interpretive plaques that highlight the route of the Amman Stream in the downtown area would sustain this memory until more concrete policies and plans are developed to daylight and rehabilitate it.

The findings reveal that our recommendation for daylighting the Amman Stream requires minimum interventions in urban form because the stream is mainly covered by roads (not buildings) whose configuration is consistent with the location and orientation of the buried stream.

The results show that Amman's residents demand stream daylighting because their city lacks green and blue infrastructure and pedestrian-friendly social spaces. Amman's residents believe that such an increase in green and blue infrastructure would yield a positive impact on The Greater Amman Municipality should carry out an assessment for daylighting the Amman Stream whereby this assessment would consider the connections between climate change adaptation and mitigation and the four groups of ecosystem services: provisioning, supporting, regulating, and cultural.

There is a dearth of green and blue infrastructure in Amman. These results underscore how essential are the cultural services provided by green and blue infrastructure for Amman's residents. The Greater Amman Municipality must develop policies and plans that ensure better provision and equitable distribution of green and blue infrastructure in Amman. their overall quality of life.

require minimum intervention in the contemporary urban form because the configuration of the streets and buildings footprints is consistent with, if not almost matches, the buried stream's location and orientation. Because it is mostly roads that run atop the culverted stream, their replacement with the stream's bluegreen corridor will be less challenging had it been overlayed by buildings. Although a novel idea, daylighting the Amman Stream seems to be supported by our study participants who acknowledge the need for nature-based solutions in Amman to enhance its climate resilience and their quality of life.
While this study focused on Amman's case, its methodology and the lessons learned are beneficial for other cities within the Middle East, within hot and arid climates, and within parts of the world where access to spatial data is challenging. Methodologically, we surmounted several barriers pertaining to inaccessibility to spatial data to carry out our study. We did so by georeferencing and digitizing aerial photos and satellite images. Although labor intensive, this enabled us to build a spatial database for future investigations. We augmented our data with online surveys among Amman's residents as well as 
with archival research and in-situ observations and photography. This combined methodology can be applied to studies in similar spatial data-scarce regions. Conceptually, Amman's rapid urbanization that led to fluvial reclamation and the loss of urban water features is not a unique story. Several other cities in the region have gradually lost (or significantly altered) their urban streams and rivers such as the Beirut River in Beirut (Lebanon), the Barada River in Damascus, and the Queiq River in Aleppo (Syria).

\section{DATA AVAILABILITY STATEMENT}

We have provided the questions and datasets for the online survey in the Supplements. As for the spatial datasets presented in this article, these are not readily available because (as discussed in the article), these original datasets and their processing are extremely costly (over $\$ 50,000$ in total). Requests to access the spatial datasets should be directed tolkhirfan@uwaterloo.ca.

\section{ETHICS STATEMENT}

The studies involving human participants were reviewed and approved by The University of Waterloo's Office of Research Ethics. The participants provided their written informed consent to participate in this study.

\section{AUTHOR CONTRIBUTIONS}

LK: research design, investigation, conceptualization, methodology, formal analysis, literature review, writingreviewing and editing, supervision, funding acquisition, and project administration. NM: data curation, software, formal analysis, validation, writing, research, and visualization. BD:

\section{REFERENCES}

Abdulkarim, D. (2004). Experts' evaluation of the production and use of public spaces in Amman, Jordan (doctoral dissertation). University of Cincinnati, Cincinnati, USA.

Abshirini, E., and Koch, D. (2016). Rivers as integration devices in cities. City Territ. Arch. 3, 1-21. doi: 10.1186/s40410-016-0030-4

Abu-Khafajah, S., and Al Rabady, R. (2013). The "Jordanian" Roman Complex: reinventing urban landscape to accommodate globalization. Near East. Archaeol. 76, 186-192. doi: 10.5615/neareastarch.76.3.0186

Abu-Sharar, T. M. (2006). The Challenges of Land and Water Resources Degradation in Jordan: Diagnosis and Solutions. Dordrecht: Springer Netherlands.

Agbeja, B. O. (2010). Community perceptions on socio-economic incentives for rehabilitation of tree species on Njala University Campus, Sierra Leone. Arboricult. J. 33, 189-201. doi: 10.1080/03071375.2010.9747609

Ahmed, A. T. (2015). Water quality for irrigation and drinking water use of Aflaj in Oman. Water Sci. Technol. Water Supply 15, 421-428. doi: 10.2166/ws. 2014.125

Aken, A. R. A. (1951). Some aspects of Nymphaea in Pompeii, Herculaneum and Ostia. Mnemosyne 4, 272-284. doi: 10.1163/156852551X00309

Akkach, S. (2010). Leisure gardens, secular habits: the culture of recreation in Ottoman Damascus. Mimarlik Fakül. Dergisi 27, 67-80. doi: 10.4305/METU.JFA.2010.1.4

Al Nawas, B. (2020). Over 100 Amman Shops Claim Damage After Recent Flooding. Amman: The Jordan Times. writing, draft preparation, and literature review. All authors contributed to the article and approved the submitted version.

\section{FUNDING}

This study was funded by the Social Sciences and Humanities Research Council of Canada (SSHRC) under file number 4352016-0243. SSHRC was not involved in the study design nor in the collection, analysis, interpretation of data and the writing of this manuscript nor in the decision to submit it for publication.

\section{ACKNOWLEDGMENTS}

We thank Megan Peck and Ben Crooks for their assistance with the design of the online survey; Yasmeen Abu-Obaid for her assistance with the Arabic translations of the survey; Sophie Wang for her assistance with the maps; Natalie Cho and Seana Hadala Turkington for their assistance with the background research on ecosystem loss and on Amman's history respectively; Alison Elliot for her help with some of the GIS analysis; and David VanderWindt, Nicole Yang, Mandy (Wen Xuan) Zhang, and Regan Zink for their assistance during the fieldwork in Amman. We also offer our gratitude to the hosting venue, Columbia Global Center Amman, specifically to Mr. Jawad Dukhgan for his organizational assistance. Lastly, we would also like to extend our gratitude to the History of Jordan for allowing us to use some of their historic photos of Amman (as credited in the captions).

\section{SUPPLEMENTARY MATERIAL}

The Supplementary Material for this article can be found online at: https://www.frontiersin.org/articles/10.3389/frwa. 2021.754679/full\#supplementary-material

Al-Abed, N., and Al-Sharif, M. (2008). Hydrological modeling of Zarqa river basin - Jordan using the hydrological simulation program FORTRAN (HSPF) Model. Water Resourc. Manage. 22, 1203-1220. doi: $10.1007 /$ s11269-007-9221-9

Albright, W. F. (1925). The Jordan valley in the Bronze Age. Ann. Am. Sch. Orient. Res. 6, 13-74. doi: 10.2307/3768510

Ali, S., Patnaik, S., and Madguni, O. (2017). Microclimate land surface temperatures across urban land use/land cover forms. Glob. J. Environ. Sci. Manage. 3, 231-242. doi: 10.22034/GJESM.2017.03.03.001

Al-Kheder, S., and Khrisat, B. (2007). Assessment of the urban planning system in historic Jerash with GIS: achievements and challenges for sustainable tourism. Tour. Hosp. Plan. Dev. 4, 245-266. doi: 10.1080/14790530701797442

Al-Marshudi, A. S. (2001). Traditional irrigated agriculture in Oman: operation and management of the Aflaj system. Water Int. 26, 259-264. doi: 10.1080/02508060108686912

Ambraseys, N. N., Melville, C. P., and Adams, R. D. (2005). The Seismicity of Egypt, Arabia and the Red Sea: A Historical Review. Cambridge: Cambridge University Press.

Angel, S., Parent, J., and Civco, D. L. (2012). The fragmentation of urban landscapes: global evidence of a key attribute of the spatial structure of cities, 1990-2000. Environ. Urban. 24, 249-283. doi: 10.1177/0956247811433536

Arce, I. (2004). The Umayyad hydraulic system at Amman Citadel-collection, storage, distribution, use and sewage. OrA 13, 243-260.

Arce, I. (2008). "The Palatine City at Amman Citadel: the construction of a Palatine architecture under the Umayyads," in Residences, Castles, Settlements. 
Transformation Processes From Late Antiquity to Early Islam in Bilad alSham, eds K. Bartl, and A. Al-Razzaq Moaz (Rahden: Leidorf Verlag), 183-216.

Arnott, D. N. (2017). Macroinvertebrates Colonisation of Recently Deculverted Urban Streams. Master's thesis, Faculty of Environmental Sciences and Natural Resource Management, Norwegian University of Life Sciences, Ås, Norway.

Baniasadi, H., and Dastmalchian, A. (2014). The differentiating characteristics of societal cultures: an examination of societal values, practices and potential for change. J. Comparat. Int. Manage. 17, 1-13.

Beaulieu, J., Golden, H., Knightes, C., Mayer, P., Kaushal, S., Pennino, M., et al. (2015). Urban stream burial increases watershed-scale nitrate export. PLoS ONE 10:e0132256. doi: 10.1371/journal.pone.0132256

Bolund, P., and Hunhammar, S. (1999). Ecosystem services in urban areas. Ecol. Econ. 29, 293-301. doi: 10.1016/S0921-8009(99)00013-0

Broadhead, A. T., Horn, R., and Lerner, D. N. (2013). Captured streams and springs in combined sewers: a review of the evidence, consequences and opportunities. Water Res. 47, 4752-4766. doi: 10.1016/j.watres.2013.05.020

Broadhead, A. T., Horn, R., and Lerner, D. N. (2015). Finding lost streams and springs captured in combined sewers: a multiple lines of evidence approach. Water Environ. J. 29, 288-297. doi: 10.1111/wej.12104

Brovelli, M. A., and Minghini, M. (2012). Georeferencing old maps: a polynomialbased approach for Como historical cadastres. e-Perimetron 7, 97-110. Available online at: http://hdl.handle.net/11311/730166

Browning, I. (1982). Jerash and the Decapolis. London: Chatto and Wmdus.

Campbell, J. B. (2012). Rivers and the Power of Ancient Rome, Studies in the History of Greece and Rome. Chapel Hill, NC: University of North Carolina Press.

Charbonneau, R., and Resh, V. H. (1992). Strawberry creek on the University of California, Berkeley campus: a case history of urban stream restoration. Aquat. Conserv. Mar. Freshw. Ecosyst. 2, 293-307. doi: 10.1002/aqc.3270020402

Chatford Clark, D. L. (2007). Viewing the liturgy: a space syntax study of changing visibility and accessibility in the development of the Byzantine church in Jordan: viewing space. World Archaeol. 39, 84-104. doi: 10.1080/00438240601148798

Chen, Z., Richard, Q., Kavvas, M. L., Ohara, N., Anderson, M. L., and Yoon, J. (2011). Impact of water resources utilization on the hydrology of mesopotamian marshlands. J. Hydrol. Eng. 16, 1083-1092. doi: 10.1061/(ASCE)HE.1943-5584.0000208

Chou, R. (2013). Addressing watercourse sanitation in dense, water pollution-affected urban areas in Taiwan. Environ. Urban. 25, 523-540. doi: $10.1177 / 0956247813501140$

Chou, R. (2016). Achieving successful river restoration in dense urban areas: lessons from Taiwan. Sustainability 8:1159. doi: 10.3390/su8111159

CIWEM. (2007). De-Culverting of Watercourses. London: Chartered Institution of Water and Environmental Management (CIWEM).

Coad, B. W., and Al-Hassan, L. A. J. (1989). Freshwater shark attacks at Basrah, Iraq. Zool. Middle East 3, 49-54. doi: 10.1080/09397140.1989.106 37574

Cohen-Shacham, E., Dayan, T., Feitelson, E., and De Groot, S. R. (2011). Ecosystem service trade-offs in wetland management: drainage and rehabilitation of the Hula, Israel: ecosystem services of wetlands. Hydrol. Sci. J. 56, 1582-1601. doi: $10.1080 / 02626667.2011 .631013$

Collier, M. J. (2015). Novel ecosystems and social-ecological resilience. Landsc. Ecol. 30, 1363-1369. doi: 10.1007/s10980-015-0243-Z

Conradin, F., and Buchli, R. (2004). "The Zurich stream day-lighting program," in Enhancing Urban Environment by Environmental Upgrading and Restoration, eds J. Marsalek, D. Sztruhar, M. Guilianelli, and B. Ubonas (Dordrecht: Kluwer Academic), 277-288. doi: 10.1007/1-4020-2694-3_24

Conzen, M. R. G. (1960). Alnwick Northumberland: A Study in Town-Plan Analysis. Transactions and Papers (London: Institute of British Geographers), iii-122. doi: $10.2307 / 621094$

Cordova, C. E. (2007). Millennial Landscape Change in Jordan: Geoarchaeology and Cultural Ecology. Tucson, AZ: University of Arizona Press.

Costanza, R., d'Arge, R., de Groot, R., Farber, S., Grasso, M., Hannon, B., et al. (1997). The value of the world's ecosystem services and natural capital. Nature 387, 253-260. doi: 10.1038/387253a0

Curl, J. S., and Wilson, S. (2015). "The Oxford dictionary of architecture," in Dictionary of Architecture, $3 r d E d n$, eds J. S. Curl and S. Wilson (Oxford: Oxford University Press). doi: 10.1093/acref/9780199674985.001. 0001
Dauphin, C., Jeddou, M. B., and Castex, J. (2015). To Mecca on pilgrimage on foot and camel-back: the Jordanian Darb al-Hajj. Bull. Council Br. Res. Levant 10, 23-36. doi: 10.1179/1752726015Z.00000000029

Delibas, M., and Tezer, A. (2017). 'Stream Daylighting' as an approach for the renaturalization of riverine systems in urban areas: Istanbul-Ayamama Stream case. Ecohydrol. Hydrobiol. 17, 18-32. doi: 10.1016/j.ecohyd.2016.12.007

Department of Statistics. (2015). Population and Housing Census 2015. Amman: Department of Statistics.

El-Khalili, M. (2014). Restoration Interventions at the roman Nymphaeum in Amman: identification and evaluation. Conservat. Manage. Archaeol. Sites 16, 341-358. doi: 10.1179/1350503315Z.000000000102

Elmqvist, T., Redman, C. L., Barthel, S., and Costanza, R. (2013). "History of urbanization and the missing ecology," in Urbanization, Biodiversity and Ecosystem Services: Challenges and Opportunities: A Global Assessment, eds T. Elmqvist, M. Fragkias, J. Goodness, B. Güneralp, P. Marcotullio, R. McDonald, S. Parnell, M. Schewenius, M. Sendstad, K. Seto, C. Wilkinson (Dordrecht: Springer Netherlands), 13-30. doi: 10.1007/978-94-007-7088-1

Elmqvist, T., Zipperer, W., and Güneralp, B. (2016). "Urbanization, habitat loss, biodiversity decline: solution pathways to break the cycle," in The Routledge Handbook of Urbanization and Global Environmental Change, eds K. Seto, W. Solecki, and C. Griffith (London; New York, NY: Routledge), 139-151.

Everard, M., and Moggridge, H. L. (2012). Rediscovering the value of urban rivers. Urban Ecosyst. 15, 293-314. doi: 10.1007/s11252-011-0174-7

Faccini, F., Luino, F., Paliaga, G., Sacchini, A., Turconi, L., and de Jong, C. (2018). Role of rainfall intensity and urban sprawl in the 2014 flash flood in Genoa City, Bisagno catchment (Liguria, Italy). Appl. Geogr. 98, 224-241. doi: 10.1016/j.apgeog.2018.07.022

Faizi, M., and Omrani, A. (2012). Natural environment of Zayande-Rood and the Safavid development of Isfahan. Iran Univer. Sci. Technol. 22, 114-118. Available online at: http://ijaup.iust.ac.ir/article-1-64-en.html

Falkenmark, M. (1989). Middle east hydropolitics: water scarcity and conflicts in the middle east. Ambio 18, 350-352.

García, I. (2017). Community engagement in an urban daylighting project: a case study of a Salt Lake City Creek. J. Urban Plan. Landsc. Environ. Des. 2, 53-63. doi: 10.6092/2531-9906/5407

Gobster, P. H., and Westphal, L. M. (2004). The human dimensions of urban greenways: planning for recreation and related experiences. Landsc. Urban Plan. 68, 147-165. doi: 10.1016/S0169-2046(03)00162-2

Gregory, K. J., and Chin, A. (2002). Urban stream channel hazards. Area 34, 312-321. doi: 10.1111/1475-4762.00085

Gurung, A., Karki, R., Bista, R., and Oh, S. (2012). Peoples' perception towards urban forestry and institutional involvement in metropolitan cities: a survey of Lalitpur City in Nepal. Small Scale For. 11, 193-205. doi: 10.1007/s11842-011-9175-x

Hacker, J. M. (1960). Modern 'Amman; a social study. Edited by John Clarke I, Durham Colleges in the University of Durham. Department of Geography. Research papers series, no. 3. Durham: Durham Colleges in the University of Durham.

Hadadin, N., Qaqish, M., Akawwi, E., and Bdour, A. (2010). Water shortage in Jordan - sustainable solutions. Desalination 250, 197-202. doi: 10.1016/j.desal.2009.01.026

Haddad, N. A., Jalboosh, F. Y., Fakhoury, L. A., and Ghrayib, R. (2016). Urban adn Rural Umayyad house architecture in Jordan: a comprehensive typological analysis at Al-Hallabat. ArchNet IJAR 10:87. doi: 10.26687/archnet-ijar.v10i2.835

Hambright, K. D., and Zohary, T. (1998). Lakes Hula and Agmon: destruction and creation of wetland ecosystems in northern Israel. Wetlands Ecol. Manage. 6, 83-89. doi: 10.1023/A:1008441015990

History of Jordan. (2021). Places and Cities (An Historic Photography Database). History of Jordan. Available online at: http://www.historyofjordan.com/ jordan $2 /$ jh/photos.php (accessed August 5, 2021).

Hübner, U. (1992). "Amman before the hellenistic period," in Studies on Roman and Islamic Amman: The Excavations of Mrs. C-M Bennett and Other Investigations, eds A. Northedge, C. M. Bennett, J. Bowsher (Oxford: The British Institute in Amman for Archaeology and History by Oxford University Press), 23-25.

Imam, K. (2006). Role of urban greenway systems in planning residential communities: a case study from Egypt. Landsc. Urban Plan. 76, 192-209. doi: 10.1016/j.landurbplan.2004.09.032 
Inam, A. (2014). Designing Urban Transformation, 1st Edn. New York, NY: Routledge. doi: 10.4324/9780203728284

Jin, J. (2016). Identification Mechanism and Design Strategies for Stream Daylighting in Vancouver. (Masters of Science (Planning) Unreviewed, School of Community and Regional Planning (SCARP), University of British Columbia), University of British Columbia Library, Vancouver, BC (Canada).

Kabisch, N., Frantzeskaki, N., Pauleit, S., Naumann, S., Davis, M., Artmann, M., et al. (2016). Nature-based solutions to climate change mitigation and adaptation in urban areas: perspectives on indicators, knowledge gaps, barriers, and opportunities for action. Ecol. Soc. 21:39. doi: 10.5751/ES-08373-210239

Kadhim, M. B. (1993). The Roman Nymphaeum of Amman: a "primary artifact" in neglect. Ekistics 60, 283-287.

Kadhim, M. B., and Rajjal, Y. (1988). Amman. Cities 5, 318-325. doi: 10.1016/0264-2751(88)90021-2

Kang, C. D., and Cervero, R. (2009). From elevated freeway to urban greenway: land value impacts of the CGC project in Seoul, Korea. Urban Stud. 46, 2771-2794. doi: 10.1177/0042098009345166

Karamouz, M., and Nazif, S. (2008). Middle Eastern Hydrologic History and Water Developments. Honolulu: World Environmental and Water Resources Congress 2008: Ahupua'A. doi: 10.1061/40976(316)144

Kennedy, D. (2017). Losing-and Salvaging? The rural landscape of graeco-roman philadelphia. Palest. Explor. Q. 149, 135-161. doi: $10.1080 / 00310328.2016 .1277675$

Khirfan, L. (2010). Traces on the palimpsest: Heritage and the urban forms of Athens and Alexandria. Cities 27, 315-325. doi: 10.1016/j.cities.2010.03.009

Khirfan, L. (2011). GIS, town plan analysis, and historical archival research: understanding the links between inherited built forms and contemporary urban design. Urban Morphol. (Montréal), 5, 39-53.

Khirfan, L. (2019). "Planning and unplanning Amman: between formal planning and non-traditional agency," in The Palgrave Handbook of Bottom-Up Urbanism, eds K. Kickert and M. Arefi (London: Palgrave), 201-218. doi: 10.1007/978-3-319-90131-2_13

Khirfan, L., Mohtat, N., and Peck, M. (2020c). A systematic literature review and content analysis combination to "shed some light" on stream daylighting (Deculverting). Water Sec. 10:100067. doi: 10.1016/j.wasec.2020. 100067

Khirfan, L., Mohtat, N., Peck, M., and Chan, A. (2020d). Dataset for assessing the scope and nature of global stream daylighting practices. Data Brief 33:106366. doi: 10.1016/j.dib.2020.106366

Khirfan, L., Peck, M., and Mohtat, N. (2020a). Systematic content analysis: a combined method to analyze the literature on the daylighting de-culverting) of urban streams. MethodsX 7:100984. doi: 10.1016/j.mex.2020.100984

Khirfan, L., Peck, M. L., and Mohtat, N. (2020b). Digging for the truth: a combined method to analyze the literature on stream daylighting. Sust. Cities Soc. 59:102225. doi: 10.1016/j.scs.2020.102225

Kim, T., and Petrolia, D. R. (2013). Public perceptions of wetland restoration benefits in louisiana. ICES J. Mar. Sci. 70, 1045-1054. doi: $10.1093 /$ icesjms/fst026

Kondolf, G. M., and Pinto, P. J. (2017). The social connectivity of urban rivers. Geomorphology 277, 182-196. doi: 10.1016/j.geomorph.2016.09.028

Kondolf, G. M., and Yang, C. (2008). "Planning river restoration projects: social and cultural dimensions," in River Restoration: Managing the Uncertainty in Restoring Physical Habitat, eds S. Darby, and D. Sear (Chichester, Sussex: John Wiley and Sons), 43-60. doi: 10.1002/9780470867082.ch4

Kopestonsky, T. (2016). The greek cult of the Nymphs at Corinth. Hesperia 85, 711-777. doi: 10.2972/hesperia.85.4.0711

Kropf, K. (1996). Urban tissue and the character of towns. Urban Des. Int. 1, 247-263. doi: 10.1057/udi.1996.32

Lichtenberger, A., and Raja, R. (2020). Management of water resources over time in semiarid regions: the case of Gerasa/Jerash in Jordan. Wiley Interdiscipl. Rev. Water 7:e1403. doi: 10.1002/wat2.1403

Lichtenberger, A., Raja, R., Seland, E. H., Kinnaird, T., and Simpson, I. A. (2019). Urban-Riverine hinterland synergies in semi-arid environments: millennialscale change, adaptations, and environmental responses at Gerasa/Jerash. J. Field Archaeol. 44, 333-351. doi: 10.1080/00934690.2019.1625619

Livingstone, E. A. (2013). "The decapolis," in The Concise Oxford Dictionary of the Christian Church, 3rd edn, ed E. A. Livingstone (Oxford: Oxford University Press).
Lucke, B., Schmidt, M., al-Saad, Z., Bens, O., and Hüttl, R. F. (2005). The abandonment of the decapolis region in Northern Jordan-forced by environmental change? Q. Int. 135, 65-81. doi: 10.1016/j.quaint.2004.10.024

Lynch, K. (1981). Good City Form, 9th edn (Cambridge, MA: The MIT Press).

Lyu, R., Zhang, J., Xu, M., and Li, J. (2018). Impacts of urbanization on ecosystem services and their temporal relations: a case study in Northern Ningxia, China. Land Use Policy 77, 163-173. doi: 10.1016/j.landusepol.2018.05.022

MacAdam, H. I. (1992). "The history of Philadelphia in the classical period," in Studies on Roman and Islamic Amman: The Excavations of Mrs. C-M Bennett and Other Investigations, eds A. Northedge, C. M. Bennett, J. Bowsher (Oxford: The British Institute in Amman for Archaeology and History by Oxford University Press), 27-45.

MacDonald, W. L. (1986). The Architecture of the Roman Empire: Volume II, An Urban Appraisal. New Haven, CT: Yale University Press.

Macklin, M. G., and Lewin, J. (2015). The rivers of civilization. Sci. Rev. 114, 228-244. doi: 10.1016/j.quascirev.2015.02.004

Mahdavinejad, M., Mirzaei, F., and Ghasempourabadi, M. (2013). Application of traditional water structures as passive energy systems case: Shushtar Kats. Energy Environ. Eng. 1, 111-117. doi: 10.13189/eee.2013.010303

Maniatakou, S., Berg, H., Maneas, G., and Daw, T. M. (2020). Unravelling diverse values of ecosystem services: a socio-cultural valuation using $\mathrm{Q}$ methodology in Messenia, Greece. Sustainability 12:10320. doi: 10.3390/su122410320

Marco, S., Hartal, M., Hazan, N., Lev, L., and Stein, M. (2003). Archaeology, history, and geology of the A.D. 749 earthquake, Dead sea transform. Geology 31:665-668. doi: 10.1130/G19516.1

McComas, M. R. (1972). Geology and land reclamation. Ohio J. Sci. 72, 65-75.

Moghaddam, A. (2014). A note on the gargar irrigation system. Iran. J. Archaeol. Stud. 2, 37-49. doi: 10.22111/IJAS.2014.1523

Mosler, S. (2021). The transformative role of rivers in the evolution of urban landscapes: a case study from urban rivers of Chelmsford in Essex. J. Urban Des. 26, 95-116. doi: 10.1080/13574809.2020.1835466

Mundoli, S., Manjunatha, B., and Nagendra, H. (2017). Commons that provide: the importance of Bengaluru's wooded groves for urban resilience. Int. J. Urban Sust. Dev. 9, 184-206. doi: 10.1080/19463138.2016.1264404

Munif, A. A. (1996). Story of a City: A Childhood in Amman, ed S. Kawar (London: Quartet Books).

Namrouqa, H. (2018). Floods 'Only Beginning' of Severe Climate Change Impacts on Jordan. Amman: The Jordan Times.

Noghai, M. (2015). Four Dead as Heavy Downpour Wreaks Havoc on Amman. Amman: The Jordan Times.

Northedge, A. (1992a). "Archaeological topography," in Studies on Roman and Islamic Amman: The Excavations of Mrs. C-M Bennett and Other Investigations, eds A. Northedge, C. M. Bennett, J. Bowsher (Oxford: The British Institute in Amman for Archaeology and History by Oxford University Press), 57-61.

Northedge, A. (1992b). "Figures," in Studies on Roman and Islamic 'Amman: The Excavations of Mrs. C-M Bennett and Other Investigations, eds A. Northedge, C. M. Bennett, J. Bowsher (Oxford: The British Institute in Amman for Archaeology and History by Oxford University Press), 233-358.

Northedge, A. (1992c). "The history of Amman in the early islamic period," in Studies on Roman and Islamic Amman: the Excavations of Mrs. C-M Bennett and Other Investigations, eds A. Northedge, C. M. Bennett, J. Bowsher (Oxford: The British Institute in Amman for Archaeology and History by Oxford University Press), 47-55.

Northedge, A. (1992d). "The physical topography of Amman," in Studies on Roman and Islamic Amman: the Excavations of Mrs. C-M Bennett and Other Investigations, eds A. Northedge,C. M. Bennett, J. Bowsher (Oxford: The British Institute in Amman for Archaeology and History by Oxford University Press), 19-21.

Oliveira, V. (2016). Urban Morphology: An Introduction to the Study of the Physical Form of Cities, The Urban Book Series. Cham: Springer. doi: 10.1007/978-3-319-32083-0

Peck, M., and Khirfan, L. (2021). Improving the validity and credibility of the sociocultural valuation of ecosystem services in Amman, Jordan. Ecol. Econ. 189:107111. doi: 10.1016/j.ecolecon.2021.107111

Penn, J. R. (2001). Rivers of the World: A Social Geographical and Environmental Sourcebook. Santa Barbara, CA: ABC-CLIO.

Phong, L. H. (2015). The relationship between rivers and cities: influences of urbanization on the riverine zones-a case study of Red River zones 
in Hanoi, Vietnam. WIT Trans. Ecol. Environ. 193, 27-43. doi: 10.2495/ SDP150031

Pinkham, R. (2000). Daylighting: New Life for Buried Streams. Old Snowmass, CO: Rocky Mountain Institute.

Potter, R. B., Darmame, K., and Nortcliff, S. (2010). Issues of water supply and contemporary urban society: the case of Greater Amman, Jordan. Philos. Trans. R. Soc. A 368, 5299-5313. doi: 10.1098/rsta.2010.0182

Rapoport, A. (1988). "Levels of meaning in the built environment," in CrossCultural Perspectives in Non Verbal Communication, ed F. Poyatos (Toronto, ON: C. J. Hogrefe), 317-336.

Rapoport, A. (1990). The Meaning of the Built Environment: A Nonverbal Communication Approach. Tucson: University of Arizona Press.

Richard, J. (2012). Water for the City, Fountains for the People: Monumental Fountains in the Roman East: An Archaeological Study of Water Management. Turnhout: Brepols Publishers.

Rykwert, J. (1976). The Idea of a Town: The Anthropology of Urban Form in Rome, Italy and the Ancient World. London: Faber and Faber Limited.

Sakr, Y. (2013). Analyzing city hall, villa and tunnel in amman: the failures of cultural amalgamation at the turn of the twentieth century. Int. J. Islam. Archit. 2, 325-348. doi: 10.1386/ijia.2.2.325_1

Schmandt, J., and Kibaroglu, A. (2016). Sustainability of Engineered Rivers in Arid Lands. Austin, TX: Euphrates-Tigris and Rio Grande/Bravo.

Schyns, J. F., Hamaideh, A., Hoekstra, A. Y., Mekonnen, M., and Schyns, M. (2015). Mitigating the risk of extreme water scarcity and dependency: the case of Jordan. Water 7, 5705-5730. doi: 10.3390/w7105705

Searns, R. M. (1995). The evolution of greenways as an adaptive urban landscape form. Landsc. Urban Plan. 33, 65-80. doi: 10.1016/0169-2046(94)02014-7

Shirazi, S. A., and Kazmi, J. H. (2016). Analysis of socio-environmental impacts of the loss of urban trees and vegetation in Lahore, Pakistan: a review of public perception. Ecol. Process. 5, 1-12. doi: 10.1186/s13717-0160050-8

Silva, J. B., Serdoura, F., and Pinto, P. (2006). "Urban rivers as factors of urban (dis) integration," in 42nd ISoCaRP Congress (Istanbul).

Simmons, A. H., Köhler-Rollefson, I., Rollefson, G. O., Mandel, R., and Kafafi, Z. (1988). Ain ghazal: a major neolithic settlement in central Jordan. Science 240, 35-39. doi: 10.1126/science.240.4848.35

Slemp, C., Davenport, M. A., Seekamp, E., Brehm, J. M., Schoonover, J. E., and Williard, K. W. J. (2012). "Growing too fast:" Local stakeholders speak out about growth and its consequences for community wellbeing in the urban-rural interface. Landsc. Urban Plan. 106, 139-148. doi: 10.1016/j.landurbplan.2012.02.017

Smith, M. E. (2007). Form and meaning in the earliest cities: a new approach to ancient urban planning. J. Plan. Hist. 6, 3-47. doi: 10.1177/1538513206 293713

Sohn, W., Kim, J., Li, M., Brown, R. D., and Jaber, F. H. (2020). How does increasing impervious surfaces affect urban flooding in response to climate variability? Ecol. Indic. 118:106774. doi: 10.1016/j.ecolind.2020.106774

Solomon, S. (2011). Water: The Epic Struggle for Wealth, Power, and Civilization. New York, NY: Harper Perennial.

Song, W., and Deng, X. (2015). Effects of urbanization-induced cultivated land loss on ecosystem services in the North China Plain. Energies 8, 5678-5693. doi: $10.3390 /$ en 8065678

Tal, A., and Katz, D. (2012). Rehabilitating Israel's streams and rivers. Int. J. River Basin Manage. 10, 317-330. doi: 10.1080/15715124.2012.727825

Tuler, S. P., Webler, T., and Rhoades, J. L. (2016). Stormwater management in a time of climate change: insights from a series of scenario-building dialogues. Weather Clim. Soc. 8, 163-175. doi: 10.1175/WCAS-D-15-0048.1

Van Bavel, B., Buringh, E., and Dijkman, J. (2018). Mills, cranes, and the great divergence: the use of immovable capital goods in western Europe and the Middle East, ninth to sixteenth centuries: mills, cranes, and the great divergence. Econ. Hist. Rev. 71, 31-54. doi: 10.1111/ehr. 12571

van Riper, C. J., Landon, A. C., Kidd, S., Bitterman, P., Fitzgerald, L. A., Granek, E. F., et al. (2017). Incorporating sociocultural phenomena into ecosystem-service valuation: the importance of critical pluralism. Bioscience 67, 233-244. doi: 10.1093/biosci/biw170

Waheeb, M., and AlGhazawi, R. (2014). Roman nymphaeum in philadelphia, south levant: new excavation data. Mediter. Archaeol. Archaeom. 14, 131-142.

Walker, S. E. C. (2012). "Nymphaeum," in The Oxford Classical Dictionary, 4 th edn, eds S. Hornblower, A. Spawforth, and E. Eidinow (Oxford: Oxford University Press).

Wallace, K. J. (2007). Classification of ecosystem services: problems and solutions. Biol. Conserv. 139, 235-246. doi: 10.1016/j.biocon.2007.07.015

Walmsley, A. (1995). Greenways and the making of urban form. Landsc. Urban Plan. 33, 81-127. doi: 10.1016/0169-2046(95)02015-L

Walmsley, A., and Damgaard, K. (2005). The Umayyad congregational mosque of Jarash in Jordan and its relationship to early mosques. Antiquity 79, 362-378. doi: 10.1017/S0003598X00114152

Weinthal, E., Zawahri, N., and Sowers, J. (2015). Securitizing water, climate, and migration in Israel, Jordan, and Syria. Int. Environ. Agreem. 15, 293-307. doi: 10.1007/s10784-015-9279-4

Weitzell, R., Kaushal, S., Lynch, L., Guinn, S., and Elmore, A. (2016). Extent of stream burial and relationships to watershed area, topography, and impervious surface area. Water 8:538. doi: 10.3390/w8110538

Wild, T. C., Bernet, J. F., Westling, E. L., and Lerner, D. N. (2011). Deculverting: reviewing the evidence on the 'daylighting' and restoration of culverted rivers. Water Environ. J. 25, 412-421. doi: 10.1111/j.1747-6593.2010.00236.x

Wild, T. C., Dempsey, N., and Broadhead, A. T. (2019). Volunteered information on nature-based solutions-dredging for data on deculverting. Urban For. Urban Green. 40, 254-263. doi: 10.1016/j.ufug.2018.08.019

Winthrop, R. H. (2014). The strange case of cultural services: limits of the ecosystem services paradigm. Ecol. Econ. 108, 208-214. doi: 10.1016/j.ecolecon.2014.10.005

Yeakley, J. A., Ervin, D., Chang, H., Granek, E. F., Dujon, V., Shandas, V., et al. (2016). "Ecosystem services of streams and rivers," in River Science: Research and Management for the 21st Century, eds D. J. Gilvear, M. T. Greenwood, M. C. Thoms, P. J. Wood (Chichester: Wiley-Blackwell), 335-352. doi: 10.1002/9781118643525.ch17

Yegül, F. K., and Architectural History Foundation York. (1992). Baths and Bathing in Classical Antiquity. New York, NY: Architectural History Foundation.

Youssef, M., and Ali, B. A. (2017). Revival of forgotten rivers through recreating the cultural promenade: a case study of the revival of beirut river, lebanon. WIT Trans. Ecol. Environ. 226, 725-737. doi: 10.2495/SDP170631

Zhang, L., Xie, L., and Xiao, Y. (2021). Maximising the benefits of regulatory ecosystem services via spatial optimisation. J. Clean. Prod. 291:125272. doi: 10.1016/j.jclepro.2020.125272

Zube, E. H., Simcox, D., and Friedman, S. (1998). Desert riparian landscapes: values and change, 1981-96. Landsc. Urban Plan. 42, 81-89. doi: 10.1016/S0169-2046(98)00079-6

Conflict of Interest: The authors declare that the research was conducted in the absence of any commercial or financial relationships that could be construed as a potential conflict of interest.

Publisher's Note: All claims expressed in this article are solely those of the authors and do not necessarily represent those of their affiliated organizations, or those of the publisher, the editors and the reviewers. Any product that may be evaluated in this article, or claim that may be made by its manufacturer, is not guaranteed or endorsed by the publisher.

Copyright (c) 2021 Khirfan, Mohtat and Daub. This is an open-access article distributed under the terms of the Creative Commons Attribution License (CC BY). The use, distribution or reproduction in other forums is permitted, provided the original author(s) and the copyright owner(s) are credited and that the original publication in this journal is cited, in accordance with accepted academic practice. No use, distribution or reproduction is permitted which does not comply with these terms. 